\title{
Product Market Competition, Corporate Governance, And Managerial Slack: Evidence from Trade Liberalization
}

\author{
Farzaneh Noghani \\ Texas Tech University \\ Hamid Noghanibehambari \\ Texas Tech University
}

In this study we take an interdependent view of governance mechanisms and test the substitution perspective of the governance bundle. We hypothesize that an exogenous increase in product market competition, as an external mechanism, leads to a decrease in the level of shareholder rights in firms' governance provisions, which is a type of internal governance mechanism. Furthermore, we argue that product market competition has a negative effect on managerial wasteful corporate activities aimed to increase their personal benefits (i.e., managerial slack). We obtain an exogenous change in product market competition by utilizing large tariff reductions of the year 2000 as a quasi-natural experiment. We find support for our theoretical arguments using a longitudinal panel of firms covering the years 19902010 and applying a difference-in-differences model.

Keywords: Trade Liberalization, Governance Mechanisms, Product Market Competition, Managerial Slack, Difference-in-differences

\section{INTRODUCTION}

There is a growing interest in the interdependency of different governance mechanisms and the effectiveness of bundles of governance practices (e.g., Aguilera, Desender, Bednar, \& Lee, 2015; Bell, Filatotchev, \& Aguilera, 2014; Hambrick \& Jackson, 2000; Misangyi \& Acharya, 2014; Rediker, \& Seth, 1995; Ward, Brown, \& Rodriguez, 2009). Drawing mainly from the market equilibrium arguments of agency theory (e.g., Jensen \& Meckling, 1976), one line of research suggests that governance mechanisms substitute for each other. These scholars posit that efficiency and relative costs necessitate that only one governance mechanism be present in order to achieve effective governance (Zajac \& Westphal, 1994; Rediker, \& Seth, 1995). For instance, these authors have found a negative relationship between the use of long-term incentive plans for CEOs and internal monitoring mechanisms of firms (Zajac \& Westphal, 1994). Based on the notion of mutual enhancement, other scholars posit that governance mechanisms complement each other because the presence of two governance mechanisms increases the effectiveness of each of them (Aguilera, Filatotchev, Gospel, \& Jackson, 2008; Milgrom \& Roberts, 1992). These scholars have argued and found empirical evidence that in order to have effective 
governance, both monitoring and incentive alignment mechanisms need to be present (Aguilera et al., 2008).

Although the recent scholarly work on bundles of governance practices has greatly improved our understanding of potential contingencies among these practices, research has not adequately addressed three important issues of this complex topic. First, much of this work has been dedicated to substitutability/complementarity of CEO incentives and monitoring mechanisms and has not been extended to relations among other governance mechanisms (for an exception, see Misangyi \& Acharya, 2014). Second, there is substantially less research examining such relations between internal and external governance mechanisms (Aguilera et al., 2015). Third, previous research mainly treats governance mechanisms as exogenous, rendering the investigation of causal effects of external mechanisms, and therefore the substitution hypothesis, problematic. As several scholars point out, it is essential to examine potential relations of various governance mechanisms utilizing methodologies that enable causal inferences (Dalton, Daily, Certo, \& Roengpitya, 2003; Aguilera et al., 2015). Failure to do so could unintentionally limit the ability to make strong assertions about the robustness of previous results and to arrive at a holistic picture of how governance mechanisms are interdependent.

The purpose of this paper is, therefore, to address this failure by investigating the influence of product market competition as an external governance mechanism on internal corporate governance structure, i.e., firm provisions of shareholder rights, and on managerial wasteful practices aimed at enhancing their personal benefit such as excess expenditure and overinvestment, i.e., managerial slack. In doing so, we draw on agency theory (e.g., Jensen \& Meckling, 1976; Fama, 1980), the substitution perspective of bundles of governance mechanisms (e.g., Rediker, \& Seth, 1995), and economic models of market competition as a source of disciplining manager (e.g., Hart, 1983). Based on these literatures, we argue that product market competition substitutes for formal internal governance mechanisms in mitigating agency conflicts of shareholders and managers. Specifically, we hypothesize that an exogenous increase in product market competition leads to a decrease in the level of shareholder rights in firms' governance provisions (as one of the firms' internal governance mechanisms) and managerial slack. Put simply, our main research objective is to investigate how the external governance mechanism of competition in the product market affect the strength of firms' internal governance and managerial slack. We test our hypotheses using a quasi-natural experiment provided by the large import tariff reduction that happened in the US in the year 2000 and a difference-in-differences methodology.

Our paper makes several contributions to corporate governance research. First, we contribute to the literature on bundles of governance mechanisms by directly testing the substitution perspective. Second, we extend prior work on the interdependencies of external and internal governance mechanisms by showing how an exogenous change in external mechanisms can affect internal ones. Third, we answer governance researchers' calls to treat firms' internal governance structure as endogenous and incorporate a quasi-experiment approach and difference-in-differences models. Fourth, we contribute to the managerial slack literature by directly testing the causal effects of product market competition on managerial slack utilizing a recently introduced residual analysis to measure slack. 


\section{FIGURE 1 \\ PRODUCT MARKET COMPETITION, CORPORATE GOVERNANCE, AND MANAGERIAL SLACK}

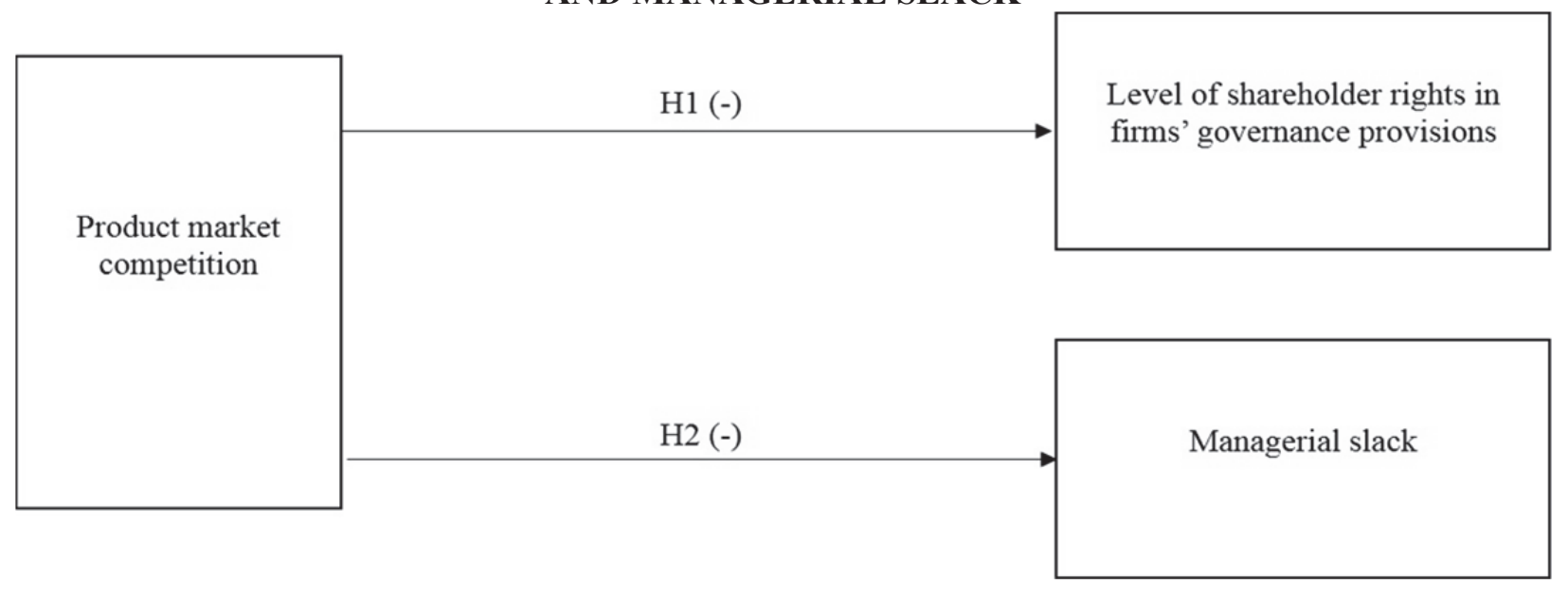

\section{THEORY AND HYPOTHESES}

\section{Corporate Governance Mechanisms}

Corporate governance refers to "formal structures, informal structures, and processes that exist in oversight roles and responsibilities in the corporate context" (Hambrick, Werder, \& Zajac, 2008: 381). Most of the research in this area has been informed by arguments of agency theory. Agency theory holds that due to the separation of ownership and control in modern organizations agency problems between managers and owners arise in the sense that managers may seek to maximize their own interests even at the expense of shareholders' interests (Jensen \& Meckling, 1976; Fama, 1980; Fama \& Jensen, 1983). These problems are results of conflict of interests, the notion that humans are boundedly rational, selfinterested, and opportunistic, and the fact that monitoring is costly (Eisenhardt, 1989). When monitoring is low the self-interest maximization of managers increases. Consequently, several governance mechanisms have been proposed that focus on mitigating the agency problems, i.e., constraining executives to manage the firm in the direction of maximizing shareholders' benefits.

Such mechanisms can be classified based on two dimensions. The first dimension categorizes mechanisms based on whether they are internal to the firm, such as board of directors, or external, such as the market for corporate control (Walsh \& Seward, 1990). The second dimension concerns whether the mechanism aligns executives' interests with those of shareholders, for example through equity ownership of executives, or monitors decisions and behaviors of executives, for instance by means of board of directors (Beatty \& Zajac, 1994; Misangyi \& Acharya, 2014). In sum, several internal or external mechanisms can be used to either align managers' and owners' interests or curb managers opportunism through monitoring their behaviors.

Corporate governance literature has been predominantly occupied with internal governance mechanisms and their effectiveness in protecting shareholder rights, balancing demands of internal and external stakeholders, and preventing executives from acting to the detriment of firm (Aguilera et al., 2015). The internal governance mechanisms mostly studied in this literature consists of four sets of board of directors, governance provisions, executive contingent compensation, and managerial equity ownership. The first set of mechanisms include board independence, board size, board ownership, and CEO duality. According to agency theory, the primary role of board of directors is to monitor management activities to make sure they are in the interest of shareholders (e.g., Fama \& Jensen,1983). Consequently, the presence of independent directors, i.e., directors who don't have a material relationship with the management or the firm, is considered critical for monitoring CEOs actions (Boyd, 1994; Finkelstein, Hambrick, \& Cannella, 2009). Furthermore, smaller boards benefit from easier 
communication and coordination which results in more efficient monitoring and reduces coordination costs (Yermack, 1996). With respect to board ownership, this mechanism has been proposed to contribute to directors' vigilance in monitoring executives' activities by aligning directors' incentives with shareholders interests (Hambrick \& Jackson, 2000). Finally, separation of CEO and chairman of the board corresponds to greater monitoring strength of the board (Fama \& Jensen, 1983; Goyal \& Park, 2005). The second set of governance mechanisms refers to the level of shareholder rights in several categories such as voting and takeover (Gompers, Ishii, \& Metrick, 2003). More details on this mechanism are provided later. The third and fourth sets of internal governance mechanisms serve as CEO incentive alignment mechanisms. These mechanisms work on the basis that tying CEO compensation to firm performance and granting them equity ownership aligns the interest of CEOs and shareholders (Jensen \& Meckling, 1976). Although there has been an extensive amount of research on the effects of each of the internal governance mechanisms on firm performance, meta-analyses show inconclusive results for such effects (e.g., Dalton, Daily, Ellstrand, \& Johnson, 1998; Dalton et al., 2003).

Several external governance mechanisms have been also proposed to act to mitigate the agency problem. These mechanisms include monitoring by large outside shareholders (Demsetz \& Lehn, 1985), the threat of takeover or the market for corporate control (Fama, 1980; Jensen \& Murphy, 1990), product market competition (Diamond, 1984; Hart, 1983; Jensen \& Murphy, 1990; Moyer, Rao, \& Sisneros, 1992; Rediker, \& Seth, 1995), and the managerial labor market (Fama, 1980; Jensen \& Murphy, 1990). When external shareholders hold large blocks of a firm's equity, they are more willing and more able to monitor management (Dalton, Hitt, Certo, \& Dalton, 2007). The market for corporate control refers to the notion that the threat of takeover acts as means of disciplining managers who have acted in the direction of their own self-interests. These managerial inefficiencies result in firm's undervaluation in the market and its increased vulnerability to a hostile takeover (Dalton et al., 2007). Competition in the product market has been proposed as another source of disciplining managers since when product competition increases managers are more likely to reduce their wasteful practices and act in the direction of firm profit maximization, otherwise the firm will not be able to compete and will go out of business (Hart, 1983). Finally, the managerial labor market refers to managers' motivation to reduce shirking and improve their performance in order to improve their reputation and enhance their position in the job market (Agrawal \& Knoeber, 1996).

\section{Bundles of Governance Mechanisms}

As discussed earlier, the evidence on the effectiveness of each of the governance mechanisms, mostly assessed in terms of their positive effect on firm performance, has been inconclusive (Dalton \& Dalton, 2011; Dalton et al., 2007). This lack of consistent results has been attributed to the fact that most of the research in this area has been exclusively done on a single form of governance mechanisms without considering their interdependencis (Aguilera et al., 2008; Dalton et al., 2003). Thus, several scholars posit that effectiveness of governance mechanisms in mitigating the agency problem depends on how they work together as a bundle (e.g., Aguilera et al., 2008; Dalton et al., 2003; Rediker \& Seth, 1995). Aside from theoretical grounds for the dependency of firm performance on a bundle of governance mechanisms rather than a single one, estimation and statistical grounds also help to explain why using a single mechanism for predicting firm outcomes is problematic. Studies on single mechanisms assume that different governance mechanisms are independent of each other; violation of such an assumption, evident from several theoretical and empirical works, results in the issue of omitted variables and therefore, biased and inconsistent coefficients in such studies (Rediker \& Seth, 1995).

The call for more research on the bundle of governance mechanisms has been addressed in two distinct ways. On the one hand, it has been suggested that governance mechanisms substitute for each other (e.g., Dalton et al., 2003; Moyer et al., 1992; Rediker \& Seth, 1995; Zajac \& Westfall, 1994). Other researchers, however, suggest that these mechanisms complement each other (e.g., Aguilera et al., 2008; Milgrom \& Roberts, 1992). Both of these views need further attention to the interdependencies of internal and external mechanisms and mechanisms belonging to the same alignment or monitoring dimension (Aguilera et al., 2015). 


\section{Governance Mechanisms as Complements}

As one line of research that considers the interdependencies of governance mechanisms, the complementarity perspectives holds that different governance mechanisms operate as complements. It states that each governance mechanism is more effective when complemented with the presence of another mechanism (Aguilera et al., 2008). This perspective builds on the premise that there exist an inherent synergy and mutual enhancement among governance mechanisms (Milgrom \& Roberts, 1992). In other words, governance mechanisms operate as complements "because their mutual presence increases the effectiveness of each" (Misangyi \& Acharya, 2014: 1685). Consequently, the different types that best complement each other and their level of the presence and strength is at the heart of these studies. For instance, these scholars have found that incentive alignment by CEO contingent pay is more strongly related to firm performance when monitoring by large outside shareholders is also present (Tosi \& Gomez-Mejia, 1989). Almost all of this research has been dedicated to the complementarity of incentive alignment and monitoring mechanisms by stating that both of these mechanisms need to be present for an effective governance (Misangyi \& Acharya, 2014). Therefore, the relations of other types of governance mechanisms and whether they act as complements or substitutes need further attention. For instance, research is lacking with respect to how various internal monitoring mechanisms work together to affect firm performance or whether external monitoring complements internal monitoring.

\section{Governance Mechanisms as Substitutes}

Proponents of this perspective hold that governance mechanisms replace one another. For example, ownership concentration substitutes the market for corporate control since firms with high ownership concentration are less likely to be taken over (Rediker \& Seth, 1995). These scholars suggest that effective governance can be achieved via alternative mechanisms (Dalton et al., 2003). This line of thought operates on the assumptions fundamental in the conceptualization of agency theory. According to this theory, organization is viewed as a "nexus of a set of contracting relationships among individuals" and its behavior "is like the behavior of a market; i.e., the outcome of a complex equilibrium process" (Jensen \& Meckling, 1976: 311). Applying this premise to the analysis of agency costs, the authors conclude that efficiency and relative costs determine the equilibrium structure of governance mechanisms. In other words, if benefits of a mechanism outweigh its costs, it will be implemented. Therefore, the agency problem is mitigated because managers' decreased level of ownership is counterbalanced by increasing their contingent compensation or by monitoring (Jensen \& Meckling, 1976; Fama \& Jensen, 1983). Extending this notion, scholars posit that requirements of efficiency and the cost-benefit tradeoffs among governance mechanisms determine which one would be used (Demsetz, 1983; Hart, 1983; Moyer et al., 1992; Rediker \& Seth, 1995). The benefit from a mechanism depends on the extent to which it can potentially mitigate the agency problem; however, the extent of such a benefit also depends on other mechanisms which are already in use. Therefore, when determining the level of any governance mechanism, other relevant mechanisms need to be included as explanatory variables and when one mechanism is greatly activated, there is less need for the other one (Rediker \& Seth, 1995: 88). Put simply, only one mechanism or the other need to be present to achieve effective governance. Similar to the complementarity perspective, research on substitution has mainly considered how incentive alignment and monitoring substitute for one another and little attention has been paid to the substitution of different monitoring or different alignment mechanisms (Misangyi \& Acharya, 2014). Tests of this perspective are concerned with finding a negative relationship between alternative governance mechanisms, which has mainly been done between a monitoring mechanism and an incentive alignment mechanism (e.g., Betty \& Zajac, 1994; Moyer et al., 1992; Rediker \& Seth, 1995). For example, building on substitution arguments, Zajac and Westfall (1994) hypothesized and found that the level of CEO equity holding, a major alignment mechanism, is negatively related to board independence, an important monitoring technique.

To sum, the substitution perspective holds that every governance mechanism has a cost and a benefit; efficiency requires that costs and benefits associated with each one be considered in order to arrive at optimal decisions about the use of that mechanism. To the extent that one mechanism is in place and it is 
working effectively, the marginal costs of using another one would outweigh its benefits and thus its use must be reduced. It follows that the extent to which a mechanism is used depends on the use of other mechanisms (Agrawal \& Knoeber, 1996). These scholars acknowledge that a true test of the substitution perspective needs to be able to explain changes in one governance mechanism as a result of exogenous changes in another one, i.e., to establish causality (Aguilera et al., 2015). In this study, we aim to provide such a test.

Building on the core arguments of the substitution perspective, we argue that an exogenous change in external governance mechanism of product market competition leads to adjustments in the design of internal governance mechanisms. Specifically, we consider the effects of competition in the product market on firm provisions of shareholder rights in several categories such as voting and takeover. These provisions serve as an important internal governance mechanism in several respects. First, these rights give shareholders the ability to elect and replace directors, who in turn have the ability to monitor managers' activities (Gompers et al., 2003). Second, shareholder rights provide them access to the market for corporate control; they are able to discipline inefficient management by accepting a takeover (Moyer et al., 1992). If shareholders are unable to replace managers or it is difficult for them to do so, managers will have more opportunity to pursue self-interested activities. In line with this reasoning several studies have found that when shareholder rights are weak, agency costs, proxied by capital expenditures and acquisition activities, increase (e.g., Giroud \& Mueller, 2011; Gompers et al., 2003). The essence of product market competition acting as an external governance mechanism is that competition disciplines managers and provides incentives to them for not shirking since in a competitive environment firms that are managed inefficiently will be taken over (e.g., Jensen \& Murphy, 1990). When competition increases, there is less need for internal governance mechanisms. The rationale for this effect of competition is derived directly from the substitution perspective. Governance provisions that reserve strong rights for shareholders provide a benefit for the firm by mitigating the agency problem; however, such provisions involve a cost too. Therefore, when competition in the market is already providing the discipline needed to align management activities with shareholders interests, there is less need for internal governance and its importance for an effective governance diminishes because implementing them would incur costs without benefiting the firm. In line with these arguments, empirical evidence shows that firms benefit more from good governance in non-competitive industries than in competitive industries (e.g., Giroud \& Mueller, 2011). Based on this discussion, we hypothesize that an exogenous increase in product market competition leads to an adjustment in governance provisions in such a way that shareholder rights become weaker.

Hypothesis 1. An exogenous increase in product market competition leads to a decrease in the level of shareholder rights in firms' governance provisions.

\section{Managerial Slack}

In one of the early attempts to conceptualize a theory of the firm while acknowledging the consequences of the separation of ownership and control, Williamson (1964) formalized a managerial theory of the firm which focuses on the motivations of managers. The central thesis of the theory is that managers may not act with the goal of firm profit maximization; instead, they are motivated to maximize their own personal utility even at the expense of shareholders values. Their personal utility encompasses both monetary and non-monetary objectives and managers are willing to impose costs on the firm if it results in increases in these objectives. Managerial slack refers to managers activities to achieve these objectives. To put it more succinctly, managerial slack is defined as "wasteful corporate practices including excess expenditure, lax management, and overinvestment" which are spent at the discretion of managers "to increase their private benefits" (Fang, He, \& Conyon, 2018: 345). These practices include excess staff, non-essential organizational supplies, excess leisure expenditures, excess firm growth, and investments of firm resources in personal projects (Jensen, 1986; Williamson, 1964).

Extending this line of thought, agency theory posits that if effective governance mechanisms are not in place, managers are more likely to use the firm resources which are at their discretion for maximizing 
their own interest (Jensen, 1993). Such self-interest maximization behaviors are the essence of managerial slack. In other words, agency theory posits that, due to the separation of ownership and control managers have the opportunity to slack; this slack is the outcome of conflict of interest of managers and shareholders and the fact that managers' actions cannot be perfectly monitored by shareholders (Hart, 1983). Furthermore, when firm costs are low managers have a greater opportunity to continue their inefficient practices intended for their personal benefit, i.e., slack, and still make the acceptable profit set by shareholders. Although shareholders can monitor firm performance, since low levels of performance can be attributed to several factors they cannot make strong conclusions about managerial efforts from the performance of the firm. Consequently, even at low levels of firm profit, managerial slack can still exist (Hart, 1983). Therefore, in order to reduce managerial slack, shareholders need to implement governance mechanisms of monitoring or incentive alignment. As explained before, cost and benefits trade-offs among different governance mechanisms determine which one would be implemented and to what extent. One of such mechanisms that will provide an incentive for managers to act in the direction of shareholders' value maximization is competition in the product market (Hart, 1983; Jensen \& Murphy, 1990; Moyer et al., 1992).

The effectiveness of product market competition as a governance mechanism to reduce managerial slack can be attributed to the notion that it "makes the performances of different firms interdependent" (Hart, 1983: 367). This interdependency has two important consequences. First, when competition increases and prices go down, managers must reduce some of their excess personal costs in order to be able to hit the profit target of shareholders. Second, now the market makes slack behaviors of managers more observable and more impactful; when an exogenous shock in product competition occurs managers must stop wasting firm resources and act in the direction of firm profit maximization otherwise the firm will not be able to compete and will go out of business (Hart, 1983; Schmidt, 1997). Put simply, competition in the product market disciplines managers because firms that are managed inefficiently will not survive (Hart, 1983; Jensen \& Murphy, 1990). In line with this theorizing and consistent with prior research (e.g., Beiner, Schmid, \& Wanzenried, 2011), we advance:

Hypothesis 2. An exogenous increase in product market competition leads to a decrease in managerial slack.

\section{METHOD}

\section{Sample and Data Collection}

To test our hypothesis regarding managerial slack, we use all the firms in the US industries that their tariff data and financial and accounting data is available in Schott's (2010) trade database and Compustat database respectively. We use the replication codes provided by Pierce and Schott (2016a) and compute the ad valorem equivalent tariff rates at (six-digit NAICS) industry level. Then we merge this dataset with firm-level panel data. We restrict the sample to those firms that have at least one observation before and one after the year 2000. It leaves us with 2221 firms in 684 industries at the NAICS6 industry level. We choose a treatment window of 10 years before and after the trade liberalization shock. This time frame captures the dynamics and characteristics of firms well before and after the trade policy change. Since the results shouldn't change much with the change of the treatment window, as a robustness check we run our models with 8-, 5-, and 2-year windows as well. To test our hypothesis regarding internal governance strength, we limit this sample to firms that their governance data is available in the Investor Responsibility Research Center (IRRC) dataset for years 1996 to 2006, which results in a sample of 964 firms in 344 industries.

\section{US-China Trade Liberalization}

US tariff schedule mainly consists of two sets: Normal Tariff Relation (NTR) rates which apply to goods imported from members of the World Trade Organization and higher tariffs known as Non-NTR which apply to all non-WTO countries. Before 2000, the latter set used to serve as the baseline tariff rates 
of all non-market economies like China. However, US law set aside a channel for these countries to be treated with the NTR rates. Although such permissions were given to China as far back as 1980, political tensions during the 1990s, such as the June Fourth Incident, China-Pakistan missile deal at 1993, and 1995-1996 Taiwan Strait Crisis, shadowed uncertainty on annual approval of the renewal. In October 2000, these uncertainties were eliminated by the new bill which accorded a Permanent Normal Trade Relations status to China. The new status let Chinese industries improve their export market with benefits from NTR rates. Not all industries were affected by this change in trade policy and there are large variations among those that were (Pierce \& Schott (2016a)). A shift from Non-NTR tariff rates to NTR rates in China's imports affected more those US local industries that were protected by higher gap between Non-NTR and NTR rates compared to those with a lower gap. Therefore, this difference between Non-NTR and NTR rates is our proxy for import tariff shock and thus product market competition.

\section{Independent Variable}

\section{Product Market Competition}

As explained in the previous section, trade policy change in 2000 enabled Chinese companies to benefit from NTR tariff rates rather than initial Non-NTR tariff rates. We operationalize the exogenous increase in product market competition through this reduction in tariff rates. Use of tariff reduction as corresponding to an increase in product market competition is consistent with previous literature in strategic management (e.g., Flammer, 2015). Following recent literature in economics (Pierce \& Schott, 2016a; Pierce \& Schott, 2016b; Feler \& Senses, 2017; Autor, Dorn \& Hanson, 2018), we measure the impact of the trade policy change by the differential effect of tariffs at the industry level at 1999, one year prior to the policy change, if the annual renewal had been failed to be approved by the Congress:

NTR Gap Gij $=$ Non - NtrRate $_{j}^{1999}-$ NtrRate $_{j}^{1999}$

where $i$ indexes firm and $j$ the industry in which the firm is operating. The differential effect (NTR Gap $i j$ in equation 1)) varies widely among industries with a mean of $33 \%$ and a standard deviation of $15 \%$ (Pierce \& Schott (2016b)). Roughly 79\% of these variations can be explained by variations in Non-NTR rates set by Smooth-Hawley Tariff Act of 1930. Therefore, it brings us less concern that Non-NTR rates were designed to protect specific current (70 years later) industries. We discuss more on this issue of reverse causality in our analysis section. NTR Gaps for firms with missing values in the merged dataset are assigned a zero value since the missing data implies that they are not affected by the policy.

\section{Dependent Variables}

\section{Level of Shareholder Rights in Firms' Governance Provisions}

In this paper, we use a governance index (G-index) corresponding to the reverse of shareholder rights. In other words, the higher the G-index, the weaker the shareholder rights. This index is constructed by measuring the relative power of shareholders and managers in several corporate decisions such as takeovers. It was first developed by Gompers et al. (2003) from 24 categories of corporate decisions. The index is freely accessible through IRRC.

\section{Managerial Slack}

Following Fang et al. (2018), we measure managerial slack as the abnormal level of General and Administrative (G\&A) expense. This variable contains expenses controlled by CEOs except selling and financial expenses and for each firm/year is available in Compustat. We compare it with the normal (i.e., predicted) level and the residual is our slack variable. The normal level of these expenses is predicted based on several factors such as firm size, assets, R\&D, advertising, etc. Following Fang et al., (2018), the residual of equation 2) serves as an appropriate measure of managerial slack. For robustness checks, we use the same procedure as Fang et al. and test other commonly used variables in our residual model. 


$$
\begin{aligned}
& \log (G \& A)_{i j t}=\beta_{0}+\beta_{1} \log (\text { Sale })_{i t}+\beta_{2}\left(\frac{P P E}{\text { Asset }}\right)_{i t}+\beta_{3}\left(\frac{E m p}{\text { Sale }}\right)_{i t}+\beta_{4}\left(\frac{\text { Asset }}{\text { Sale }}\right)_{i t} \\
& +\beta_{5}\left(\text { R\& } \frac{D}{\text { Sale }}\right)_{i t}+\beta_{6}\left(\frac{\text { Adv }}{\text { Sale }}\right)_{i t}+\beta_{7}(\text { SaleGrowth })_{i t, t-3} \\
& +\beta_{8}(\text { SaleFall })_{i t, t-1}+\gamma t+\zeta j+\xi i+v i j t
\end{aligned}
$$

In this formula, firm's characteristics include logarithm of annual sale $(\log (\operatorname{Sale}))$ for firm $i$ at industry $j$ in year $t$, intensity of tangible assets computed as expenditures on property, plant and equipment over total assets (PPE/Asset), employment intensity measured as number of employees divided by total annual sales (Emp/Sale), asset over sales which indicates asset intensity (Asset/Sale), research and development costs intensity (R\&D/Sales), advertisement expenditure intensity (Adv/Sale), three years growth rates in sales (Sale Growth), and a dummy that equals 1 if the firm experienced a decrease in sale since last year (SaleFall). $\gamma$ includes dummies for universal macroeconomic shocks. Industry-specific time-invariant features are captures by $\zeta$. We modify the model of Fang et al. (2018) by including firm's fixed effects in $\xi$ to capture all firm-specific inherent characteristics that do not vary over time but can explain the variation in G\&A. In order to check for the robustness of our measure of managerial slack, we use four other alternative measures. First, following (Luo, Zhang, \& Zhu 2011), we scale G\&A by total asset and insert the modified dependent variable in equation 2), and the residual denoted by Resid G\&A/ Asset is an alternative measure of managerial slack. Second, we follow (Chen, Lu, \& Sougiannis 2012) and replace the dependent variable of equation 2) with the logarithm of Selling, General, and Administrative costs (SG\&A) and the slack is (Resid SG\&A). Third, we make another measure of slack by combining the two methods and scaling the $S G \& A$ costs by assets and replacing it with the DV in equation 2) and finding the altered residuals named as Resid $S G \& A / A s s e t$. Fourth, we use a more conventional method suggesting the intensity of $G \& A$ costs as a measure of managerial slack, $G \& A /$ Sales (Singh, 1986).

\section{Control Variables}

NTR rates affect the exporters' profits and the local market competition. Thus, we include them as the main covariates in all models. Log of assets is included as a proxy of firm size. The results are quite robust and similar when we take the log of employees as the measure for firm size. Since slacks could partly be explained by changes in firm size rather than only the level of the firm's size (Fang et al., 2018), we include a 1-year sale growth as a control variable. Some firms were initially in industries with high local market competition and so the trade policy could have a much lower effect on their competition while some firms in low competition markets could be more affected by the same degree of exposure to foreign market imports. Therefore, we include the Herfindahl-Hirschman index (HHI) of industry concentration in the year 1999, one year prior to the policy change, to control for this initial state effect. Other control variables include: Intensity of net cash flow of operating activities defined as net cash flow of operating activities divided by total assets (CF intensity), leverage ratio (LR), and return on asset (ROA).

\section{Analysis}

\section{The Multilevel Modeling Issues}

Interpretation of the results of a multilevel regression can be problematic due to some fallacies such as atomistic or ecological fallacies (Huang, 2018b). We posit that the model used in this paper can take care of this problem. First, as a rule of thumb, the fallacy is likely to cause a problem when we have at least 30 observations per each cluster. In our study, there are fewer than 6 firms per industry (i.e., cluster). Thus, there is less of a need to go from a panel data fixed effect model to alternatives such as multilevel modeling (Huang, 2018b; Wooldridge, 2015). Second, even if we had a smaller sample of industries, the multilevel analysis leads to lower standard errors and it usually does not change the estimates of coefficients. Therefore, the main problem to solve is correcting for the deflated standard errors. The most recent literature (e.g., Bell \& Jones, 2015; Huang, 2018a; Schurer \& Yong, 2012; Wooldridge, 2015) 
offers some ways to solve for this issue. First, clustering for standard errors at the level of aggregation, i.e. industry, which can take care of the clustering bias in the estimate or the intercorrelation at the industry level. Second, using a panel fixed effect model which is called the golden solution to account for this fallacy (Wooldridge, 2015). Here we use a panel fixed effect model and cluster the standard errors at the industry level. Thus, deflated standard errors will be less of a concern.

\section{Reverse Causality}

One potential concern is the presence of selection bias in the portfolio of industries for which NonNTR rates were applied initially. If the government intended to protect specific industries because of their lower competitiveness in the global economy, surging imports, or declining employment, then firms and industry characteristics can explain Non-NTR tariff rates and the regressions suffer from reverse causality. However, as noted by Pierce \& Schott (2016b) up to 79\% of the variations in NTR-Gap can be explained by Non-NTR rates that had been set 70 years before the change in China's PNTR status. This fact implies that reverse causality is not deteriorating the estimates. However, to check whether the industry characteristics prior to the policy change could explain the Non-NTR rates and NTR-Gaps, we run some industry fixed effect regression with 9-year industry average in sale growth, employment growth, and import growth as the independent variables of interest. The results are reported in Table 3. None of the industry characteristics have explanatory power for variations in Non-NTR rates nor for NTR-Gaps. Therefore, reverse causality is not a concern in our analysis.

\section{Difference-in-differences Method}

We utilize a quasi-natural experiment and analyze the data with a difference-in-differences (DID) methodology. Here our treatment is the large reduction in import tariff rates in 2000. In order to investigate the effect of market competition on the dependent variables we use different forms of the following model:

$$
\begin{aligned}
& D V_{i j t}=\theta \text { Post } \times N T R \text { Gap }_{i j}+\alpha_{1} N T R_{j t}+\alpha_{2} \text { Post } \times N T R_{j t}+\alpha_{3} X_{i j t}+ \\
& \alpha_{4} \text { Post } \times X_{i j t}+\gamma_{t}+\zeta_{j}+\xi_{i}+v_{i j t}
\end{aligned}
$$

where $i$ is the index of the firm, $j$ the industry and $t$ the year of observation. This equation examines whether firms with higher NTR gaps (first difference) experience differential changes in the DV after the shock caused by the change in the US trade policy (second difference). The DID term of interest, the interaction of a universal space-invariant time indicator Post (equals 1 if year $>2000$ ) and a timeinvariant firm-specific NTR Gap, reveals the effect of the trade shock. Therefore, $\theta$ captures the effect of the change in trade policy with China in 2000 by comparing firms with different NTR Gaps over time. Normal rates are included in sub-industry time-variant NTR. Matrix $X$ represents a firm's control variables such as size and leverage. $\gamma$ contains a series of time fixed effect vectors. Aggregate timeinvariant industry fixed effects are included in $\zeta . \xi$ represents all inherent firm features that do not vary over time (firm fixed effects). The DID model can compare the firms with high and low gaps over time and so isolate the effect of the trade policy shock. Generalizing the DID from a two-year time period into a panel data model with time fixed effects and industry fixed effects grants a more flexible estimation which could also reveal the longer-term effects of the change in policy on firms.

\section{RESULTS}

Table 1 depicts a summary statistics for treated and control firms and descriptive statistics and correlations for the variables in our study are presented in Table 2. 


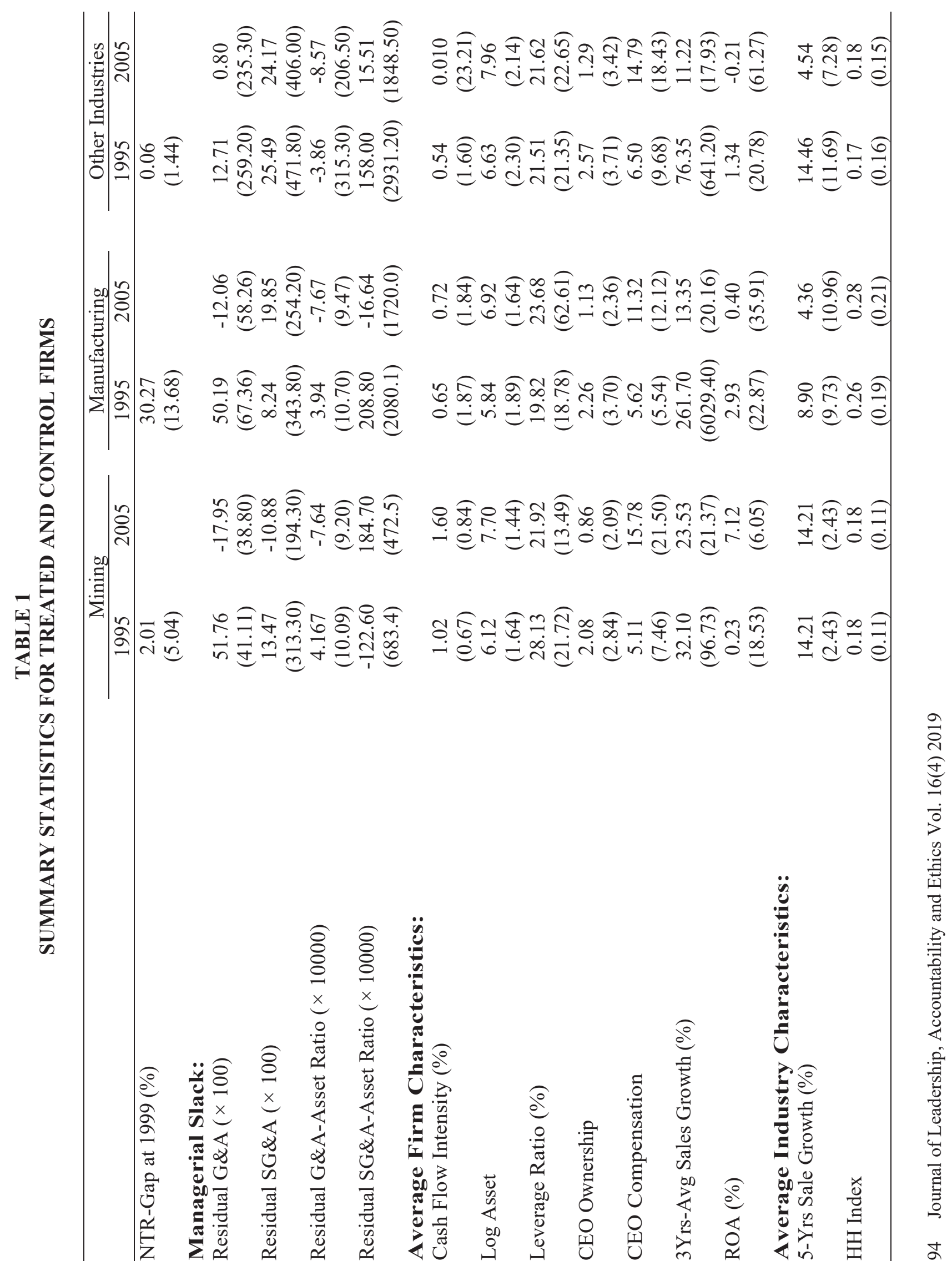




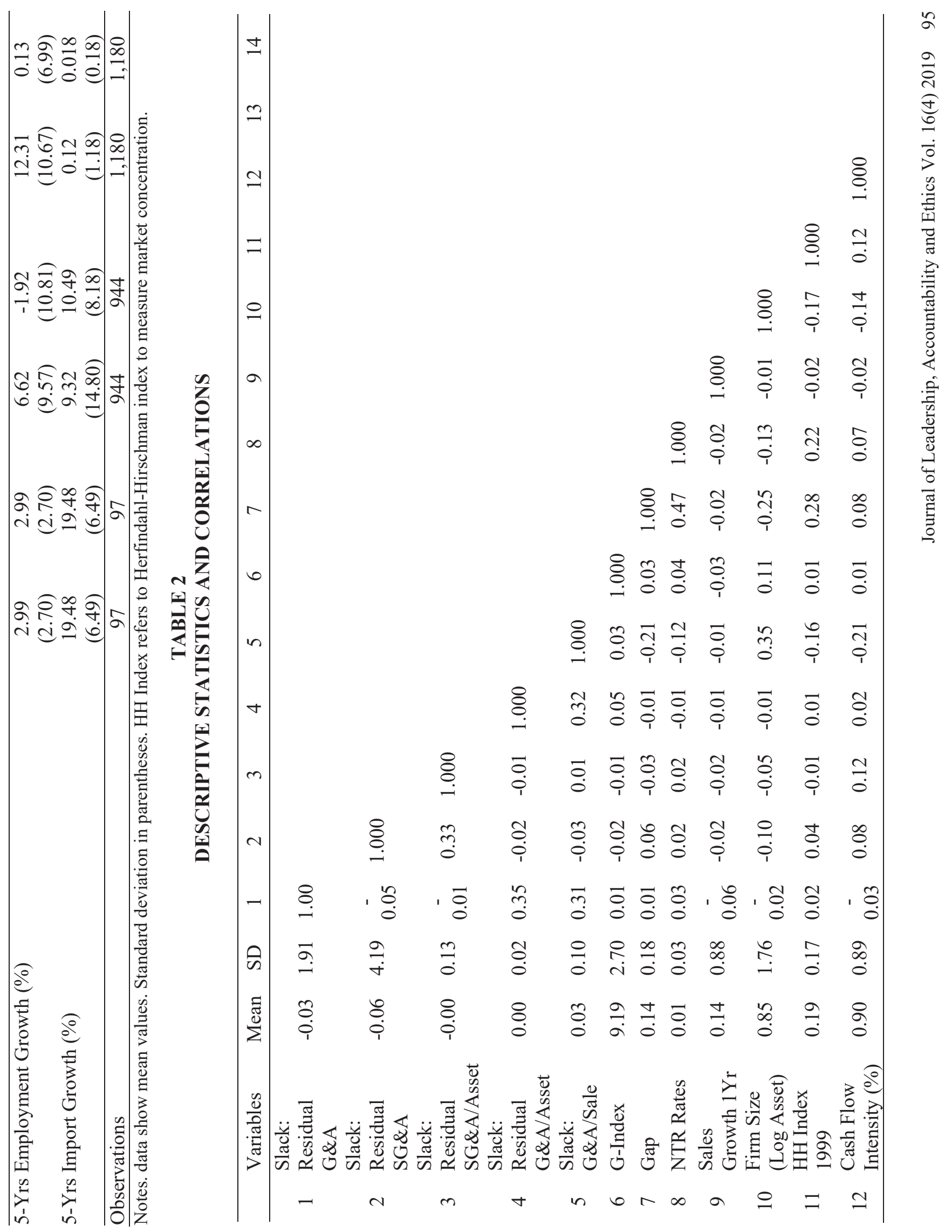




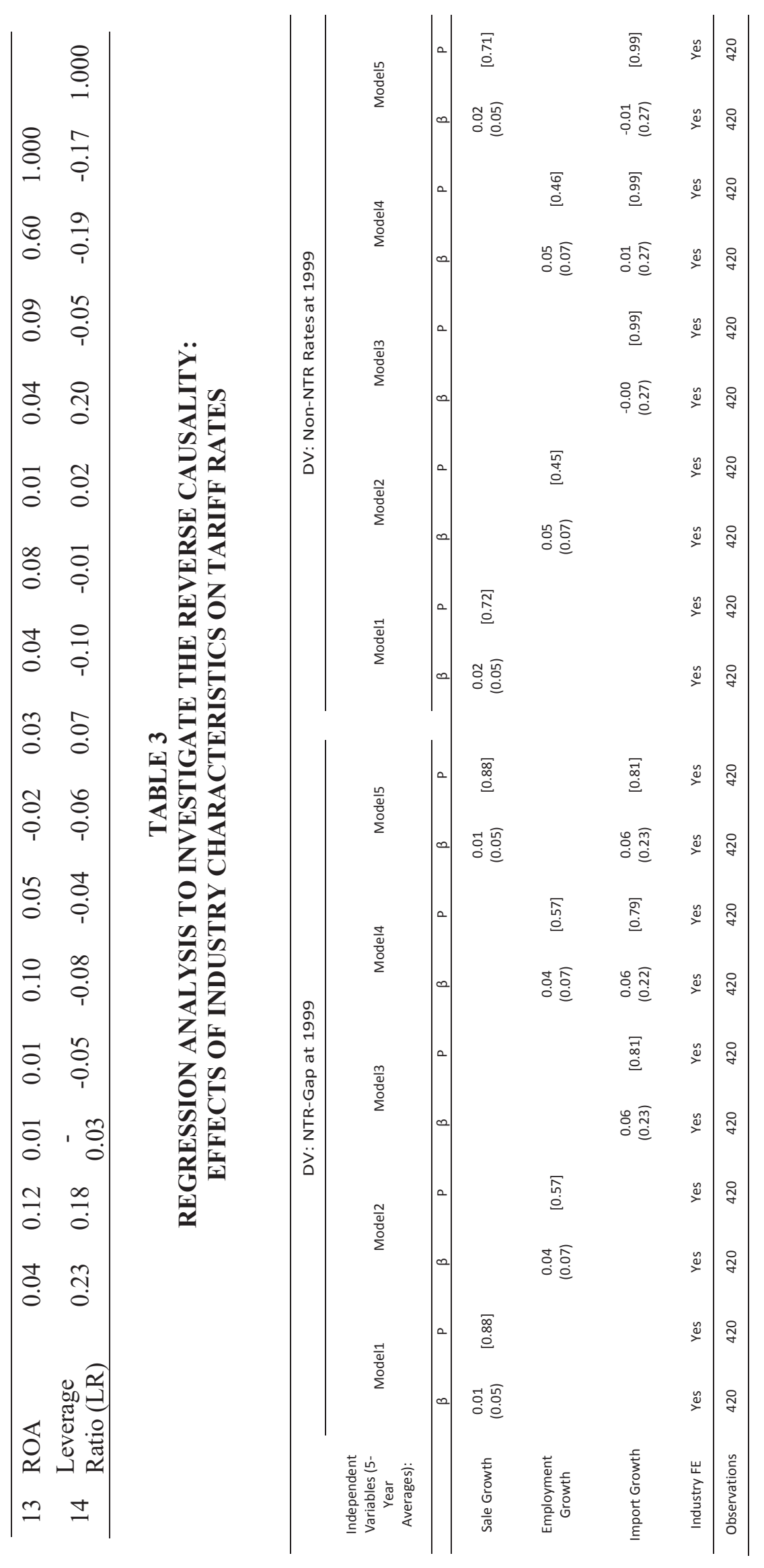


Since firms in mining and manufacturing were the most affected industries, we split the sample into three groups: manufacturing, mining, and all other industries. We show average characteristics for two illustrative years 1995 and 2005. As shown in the first row, the NTR Gap was largest (30.27\%) for firms in manufacturing and lowest $(0.06 \%)$ for other industries. Also, our main measure of slack, Resid G\&A, reveals the largest reduction among firms in manufacturing and lowest among other industry groups. Comparing firms' average characteristics, there is no pronounced difference between firms in different groups. Average industry facets, and most importantly to our analysis, initial HH-Index, are quite similar in all three groups. Figure 1 illustrates the distribution of two sets of tariffs, namely NTR and Non-NTR rates across US industries in the year 1999. The higher difference between these two schedules, i.e. higher initial tariff gap, leads to larger reductions in tariffs. Firms in the mining and manufacturing industries are most affected by the trade policy change and so experienced a higher competition in the output market. As shown in Figure 2, these firms reduced their managerial slacks substantially for the years after 2000 compared to the previous years (first difference) while for firms in other industries (with zero initial gap) the measure of managerial slack did not change during the same time span (second difference).

FIGURE 2

THE DISTRIBUTION OF NTR AND NON-NTR TARIFF RATES ACROSS US INDUSTRIES IN THE YEAR 1999

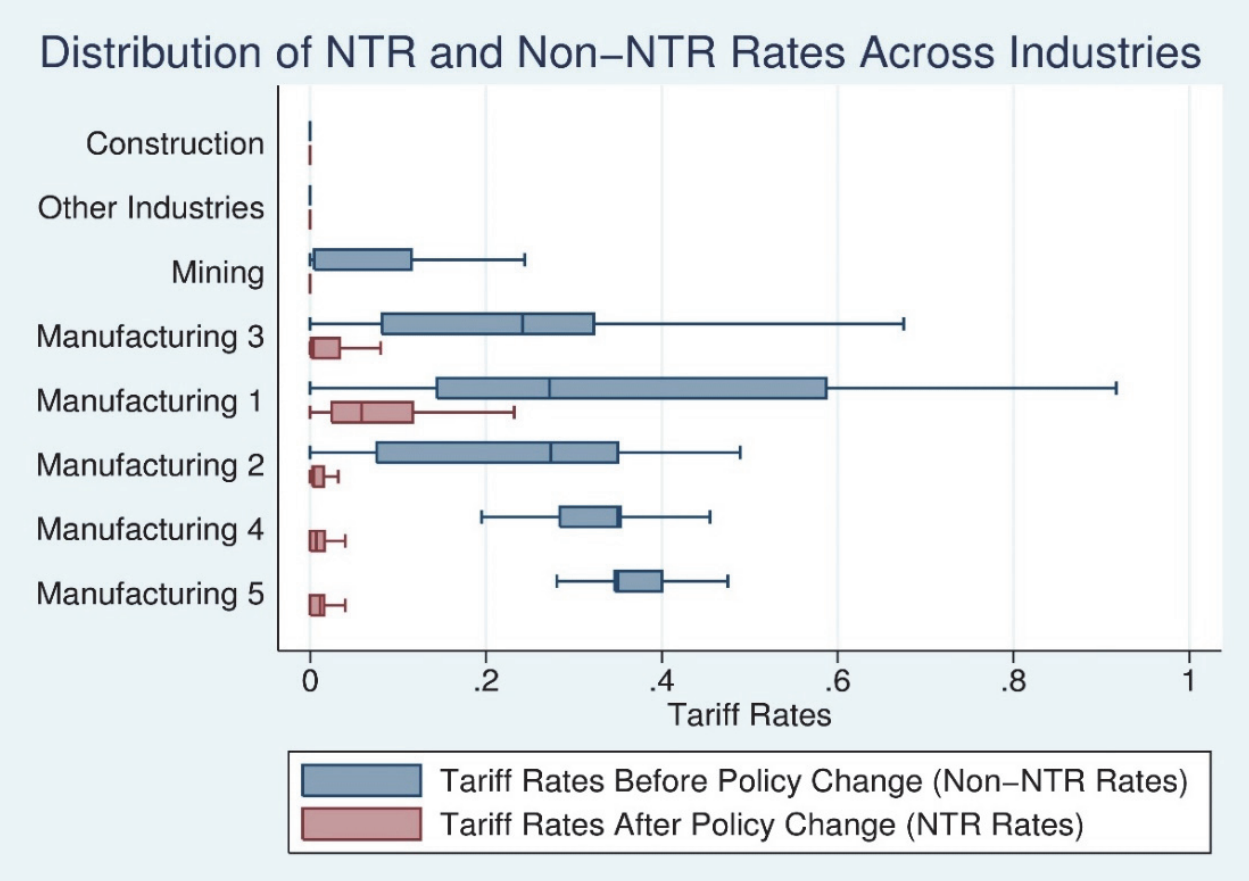




\section{FIGURE 3 \\ EVOLUTION OF MANAGERIAL SLACK FOR TREATMENT AND CONTROL GROUPS BEFORE AND AFTER THE TRADE LIBERALIZATION}

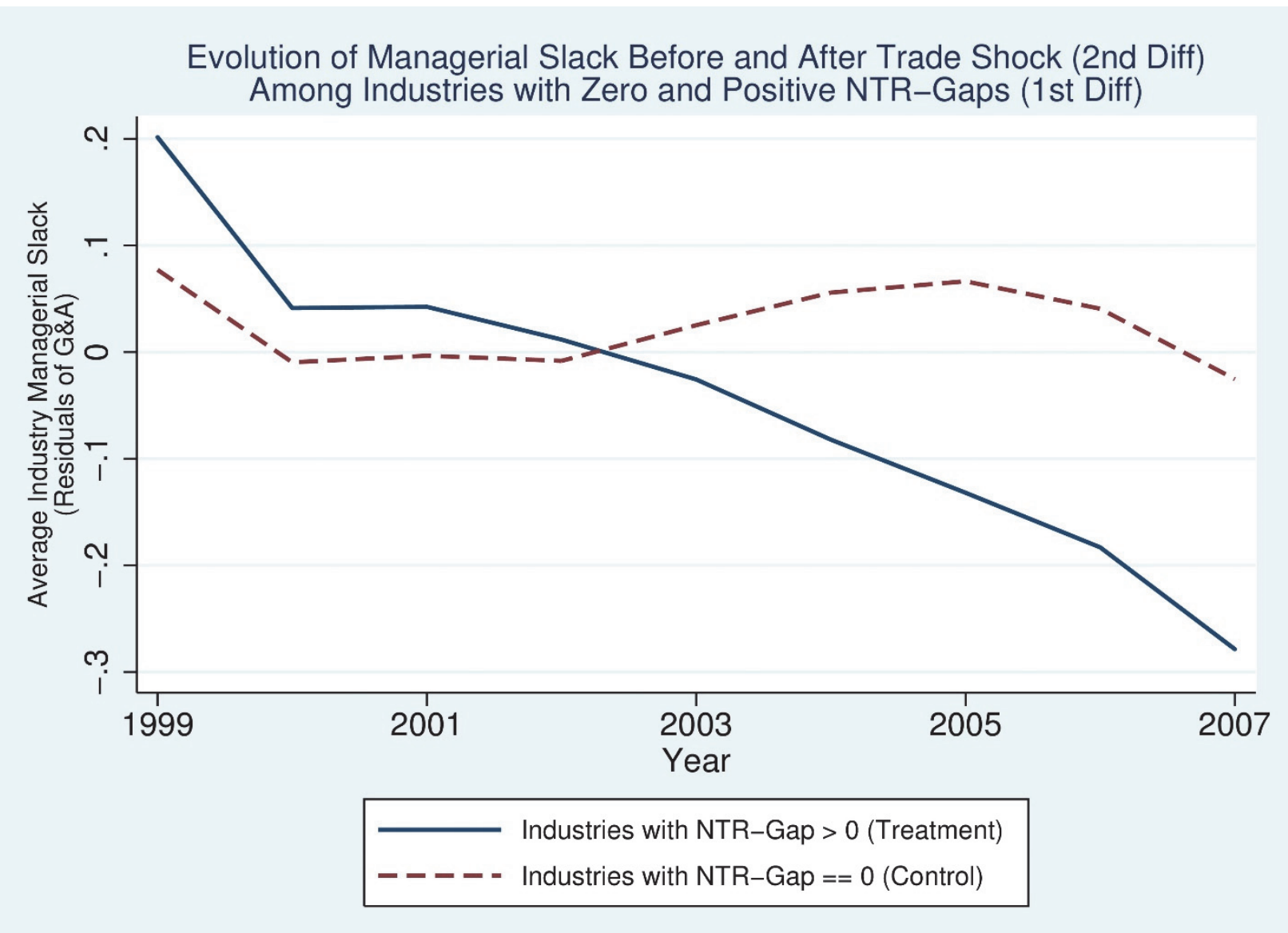

Hypothesis 1 predicts that an increase in product market competition leads to a decrease in the level of shareholder rights. Table 4 reports the results for this hypothesis. We use a simple difference-indifference estimation in which the coefficient of interest Post $\times$ NTR Gap in Table 4 shows the effect of initial tariff gap (first difference) for the period after 2000 (second difference) on G-Index. As was mentioned previously, a higher G-Index corresponds to a lower level of shareholder rights. Although the magnitude of the coefficient of interest varies in different specifications it remains significant. Model 1 reveals a simple year-adjusted correlation between trade shock and G-Index. A 1\% higher initial tariff gap is reflected in $1.1 \%$ increase in G-Index after the year 2000. The correlation is significant at $1 \%$ level. In our full model, model 6, the coefficient of Post $\times$ NTR Gap shows that a 1\% increase in the initial gap is associated with $0.61 \%$ increase in G-Index, or $0.61 \%$ decrease in the level of shareholder rights (i.e., internal governance strength). Therefore, Hypothesis 1 is supported. 
TABLE 4

THE EFFECTS OF PRODUCT MARKET COMPETITION (TRADE LIBERALIZATION) ON G-INDEX (REVERSE OF THE LEVEL OF SHAREHOLDER RIGHTS IN FIRMS' GOVERNANCE PROVISIONS)

\begin{tabular}{|c|c|c|c|c|c|c|}
\hline Variables & Model 1 & Model 2 & Model 3 & Model 4 & Model 5 & Model 6 \\
\hline Post* NTR Gap & $\begin{array}{l}1.102^{* *} \\
(0.476)\end{array}$ & $\begin{array}{c}0.809 \\
(0.498)\end{array}$ & $\begin{array}{l}1.116^{* *} \\
(0.525)\end{array}$ & $\begin{array}{l}1.373^{* *} \\
(0.533)\end{array}$ & $\begin{array}{l}0.903^{* *} \\
(0.356)\end{array}$ & $\begin{array}{l}0.608^{*} \\
(0.363)\end{array}$ \\
\hline NTR Rates & & $\begin{array}{c}4.833^{*} \\
(2.796)\end{array}$ & $\begin{array}{l}8.479 * * \\
(3.839)\end{array}$ & $\begin{array}{l}8.973^{* *} \\
(3.859)\end{array}$ & $\begin{array}{c}15.896^{* *} \\
(7.842)\end{array}$ & $\begin{array}{c}15.589^{* *} \\
(7.842)\end{array}$ \\
\hline Post* NTR Rates & & & $\begin{array}{l}-8.716 \\
(5.536)\end{array}$ & $\begin{array}{l}-9.313^{*} \\
(5.544)\end{array}$ & $\begin{array}{c}-5.376^{* * *} \\
(1.953)\end{array}$ & $\begin{array}{c}-5.477^{* * *} \\
(1.935)\end{array}$ \\
\hline Cash flow Intensity & & & & $\begin{array}{l}0.140^{* * *} \\
(0.042)\end{array}$ & & $\begin{array}{c}0.052 \\
(0.039)\end{array}$ \\
\hline $\begin{array}{l}\text { Post* Cash Flow } \\
\text { Intensity }\end{array}$ & & & & & & 0.030 \\
\hline Firm Size (Log Asset) & & & & $\begin{array}{l}0.147^{* * *} \\
(0.034)\end{array}$ & & $\begin{array}{c}(0.060) \\
-0.184^{*} \\
(0.111)\end{array}$ \\
\hline Post* Firm Size & & & & & & $\begin{array}{l}-0.064^{*} \\
(0.033)\end{array}$ \\
\hline Leverage Ratio (LR) & & & & $\begin{array}{c}0.289 \\
(0.352)\end{array}$ & & $\begin{array}{c}0.143 \\
(0.402)\end{array}$ \\
\hline Post* LR & & & & & & $\begin{array}{r}-0.024 \\
(0.305)\end{array}$ \\
\hline Firm FE & No & No & No & No & Yes & Yes \\
\hline Time FE & Yes & Yes & Yes & Yes & Yes & Yes \\
\hline $\mathrm{F}$ & $22.231^{* * *}$ & $16.286^{* * *}$ & $13.086^{* * *}$ & $11.119^{* * *}$ & $11.739^{* * *}$ & $11.806^{* * *}$ \\
\hline Observations & 1994 & 1994 & 1994 & 1928 & 1994 & 1928 \\
\hline
\end{tabular}

The main results of our Hypothesis 2 are reported in Table 5. The dependent variable in this table is the residuals of G\&A in a full specification model introduced in equation 2). The coefficient of Post $\times$ NTR Gap is the DID term of interest which captures the effect of product market competition shock on managerial slack. The first three models show the conditional correlation between the shock and managerial slack. In model 5 a full specification model is reported. Controlling for firm and industry characteristics that could vary over time, and firm and industry characteristics that do not vary over time (fixed effects), trade policy has a negative and significant effect on managerial slack. All else equal, a 1\% increase in initial tariff gap, which in turn means a $1 \%$ decrease in tariff reduction and so a respective increase in product market competition, will decrease our measure of managerial slack by $2.13 \%$. The coefficient is significant at $1 \%$ level. Comparing models 3 and 5, we can see that the effect is quite robust by including additional firm characteristics (e.g. LR, ROA, size), industry characteristics (e.g. HH-Index), and industry fixed effects. Therefore, Hypothesis 2 is supported. In the next tables, we show that the significance of the effect is robust when using four other measures of slack.

In table 6, we report the results of Hypothesis 2 when the dependent variable is the residuals of SG\&A/Asset (models 1 through 5) extracted from equation 2. The coefficients of trade shock are quite 
robust in different specifications, conditional and unconditional on firm and industry characteristics and fixed effects. The full model is reported in model 5. On average, a 1\% higher initial gap, which is translated into $1 \%$ reduction in tariff at 2000 and so increase in market competition, is associated with $0.08 \%$ decrease in the measure of managerial slack as residuals of SG\&A/Asset. All coefficients are significant at 1\% level. Table 7 reports the same models using G\&A/Sale (models 1 through 5) as the measures of managerial slack. In the full specification reported in model 5 , we see that a $1 \%$ increase in the gap, all else equal, is associated with $0.04 \%$ decrease in managerial slack, and significant at $1 \%$ level. The results for the other alternative measures of managerial slack show similar patterns; however, due to space limitations, these results are not reported here. The related tables are available upon request.

\section{TABLE 5}

\section{THE EFFECTS OF PRODUCT MARKET COMPETITION (TRADE LIBERALIZATION) ON MANAGERIAL SLACK}

\begin{tabular}{|c|c|c|c|c|c|}
\hline Variables & $\begin{array}{l}\text { Model 1 } \\
\text { (DV: Resid } \\
\text { G\&A) }\end{array}$ & $\begin{array}{c}\text { Model } 2 \\
\text { (DV: Resid } \\
\text { G\&A) }\end{array}$ & $\begin{array}{l}\text { Model } 3 \\
\text { (DV: Resid } \\
\text { G\&A) }\end{array}$ & $\begin{array}{c}\text { Model } 4 \\
\text { (DV: Resid } \\
\text { G\&A) }\end{array}$ & $\begin{array}{c}\text { Model } 5 \\
\text { (DV: Resid G\&A) }\end{array}$ \\
\hline Post* NTR Gap & $\begin{array}{c}-1.013^{* *} \\
(0.053)\end{array}$ & $\begin{array}{c}-2.186^{* * *} \\
(0.081)\end{array}$ & $\begin{array}{c}-2.554^{* * *} \\
(0.088)\end{array}$ & $\begin{array}{c}-2.129^{* * *} \\
(0.081)\end{array}$ & $\begin{array}{c}-2.129^{* * *} \\
(0.081)\end{array}$ \\
\hline NTR Rates & $\begin{array}{l}5.733^{* * *} \\
(0.498)\end{array}$ & $\begin{array}{l}3.222^{* * *} \\
(0.343)\end{array}$ & $\begin{array}{l}3.831^{* * *} \\
(0.477)\end{array}$ & $\begin{array}{l}4.082^{* * *} \\
(0.485)\end{array}$ & $\begin{array}{l}4.082^{* * *} \\
(0.485)\end{array}$ \\
\hline Post* NTR Rates & $\begin{array}{c}-5.383^{* * *} \\
(0.511)\end{array}$ & $\begin{array}{c}-1.976^{* * *} \\
(0.273)\end{array}$ & $\begin{array}{c}-1.763^{* * *} \\
(0.288)\end{array}$ & $\begin{array}{c}-1.993^{* * *} \\
(0.303)\end{array}$ & $\begin{array}{c}-1.993^{* * *} \\
(0.303)\end{array}$ \\
\hline Cash Flow Intensity (\%) & & & & $\begin{array}{l}0.031^{*} \\
(0.016)\end{array}$ & $\begin{array}{l}0.031^{*} \\
(0.016)\end{array}$ \\
\hline Post* Cash Flow Intensity & & & & $-0.041^{* *}$ & $-0.041^{* *}$ \\
\hline & & & & $(0.017)$ & $(0.017)$ \\
\hline Firm Size (Log Asset) & & & & $\begin{array}{l}0.349^{* * *} \\
(0.023)\end{array}$ & $\begin{array}{l}0.349^{* * *} \\
(0.023)\end{array}$ \\
\hline Post* Firm Size & & & & $\begin{array}{c}0.013 \\
(0.010)\end{array}$ & $\begin{array}{c}0.013 \\
(0.010)\end{array}$ \\
\hline Leverage Ratio (LR) & & & & $\begin{array}{c}-1.477^{* * *} \\
(0.118)\end{array}$ & $\begin{array}{c}-1.477^{* * *} \\
(0.118)\end{array}$ \\
\hline Post* LR & & & & $\begin{array}{l}1.541^{* * *} \\
(0.120)\end{array}$ & $\begin{array}{l}1.541^{* * *} \\
(0.120)\end{array}$ \\
\hline ROA & & & & $\begin{array}{c}-0.703^{* * *} \\
(0.130)\end{array}$ & $\begin{array}{c}-0.703^{* * *} \\
(0.130)\end{array}$ \\
\hline Post* ROA & & & & $\begin{array}{l}0.793^{* * *} \\
(0.133)\end{array}$ & $\begin{array}{l}0.793^{* * *} \\
(0.133)\end{array}$ \\
\hline Sales Growth $1 \mathrm{Yr}$ & & & & $\begin{array}{l}0.001^{* * *} \\
(0.000)\end{array}$ & $\begin{array}{l}0.001^{* * *} \\
(0.000)\end{array}$ \\
\hline Post* Sales Growth 1Yr & & & & $\begin{array}{l}-0.001^{*} \\
(0.000)\end{array}$ & $\begin{array}{l}-0.001^{*} \\
(0.000)\end{array}$ \\
\hline HH Index 1999 & & & & $\begin{array}{c}-6.062^{* * *} \\
(1.172)\end{array}$ & $\begin{array}{c}-14.229^{* * *} \\
(0.348)\end{array}$ \\
\hline Year FE & Yes & Yes & Yes & Yes & Yes \\
\hline Industry FE & No & Yes & No & No & Yes \\
\hline Firm FE & No & No & Yes & Yes & Yes \\
\hline $\mathrm{F}$ & $9.703^{* * *}$ & $1.521^{* * *}$ & $16.740^{* * *}$ & $17.400^{* * *}$ & $17.400^{* * *}$ \\
\hline Observations & 58389 & 58389 & 58389 & 58192 & 58192 \\
\hline
\end{tabular}

Notes: Standard errors in parentheses

$* \mathrm{p}<0.1, * * \mathrm{p}<0.05, * * * \mathrm{p}<0.01$ 


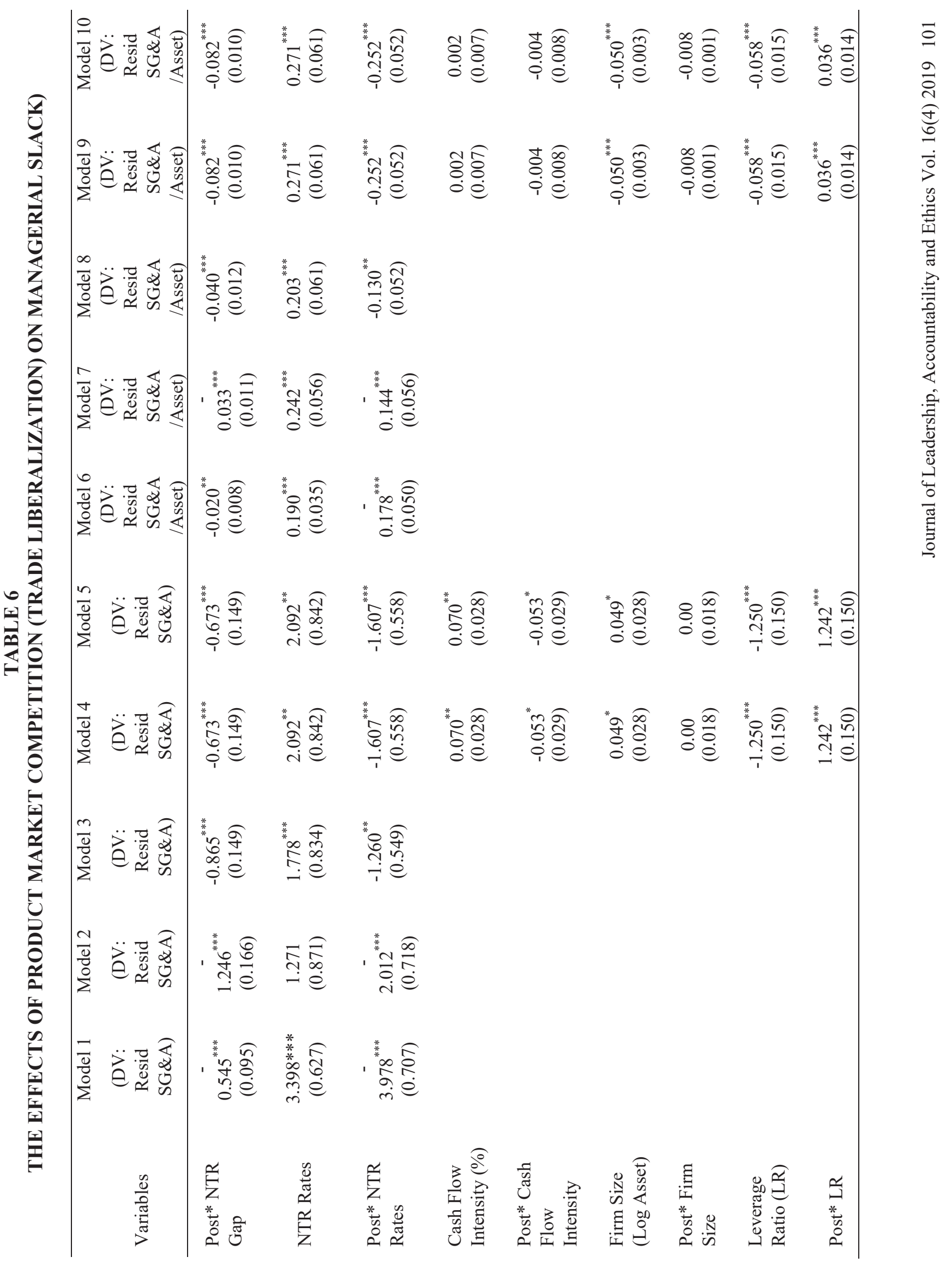




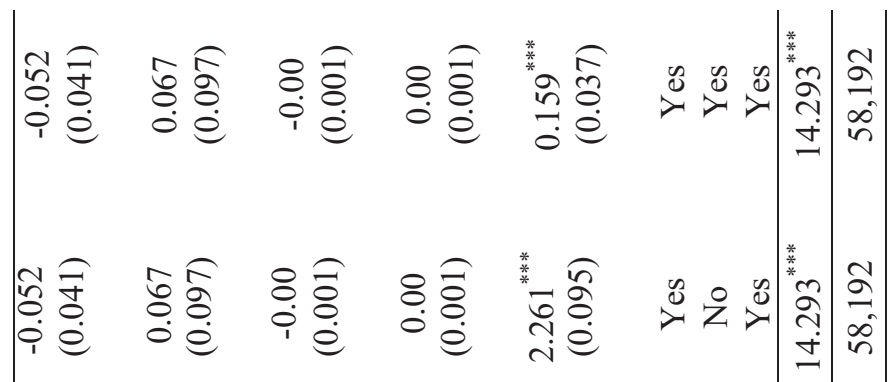

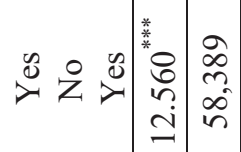

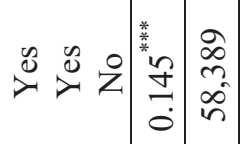

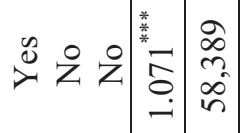

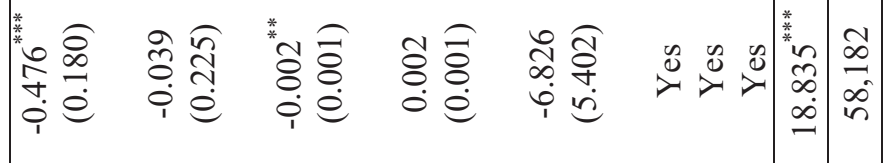

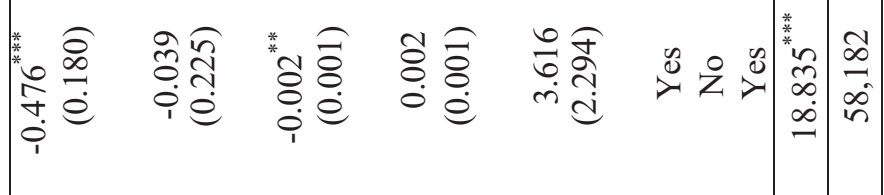

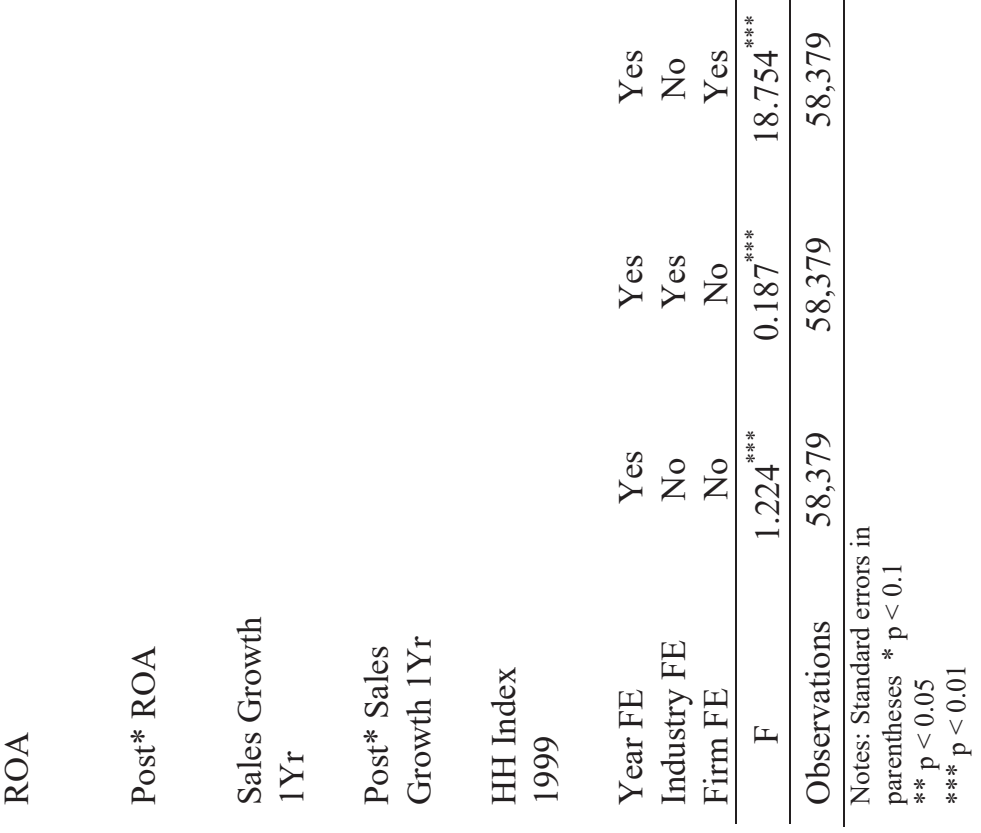




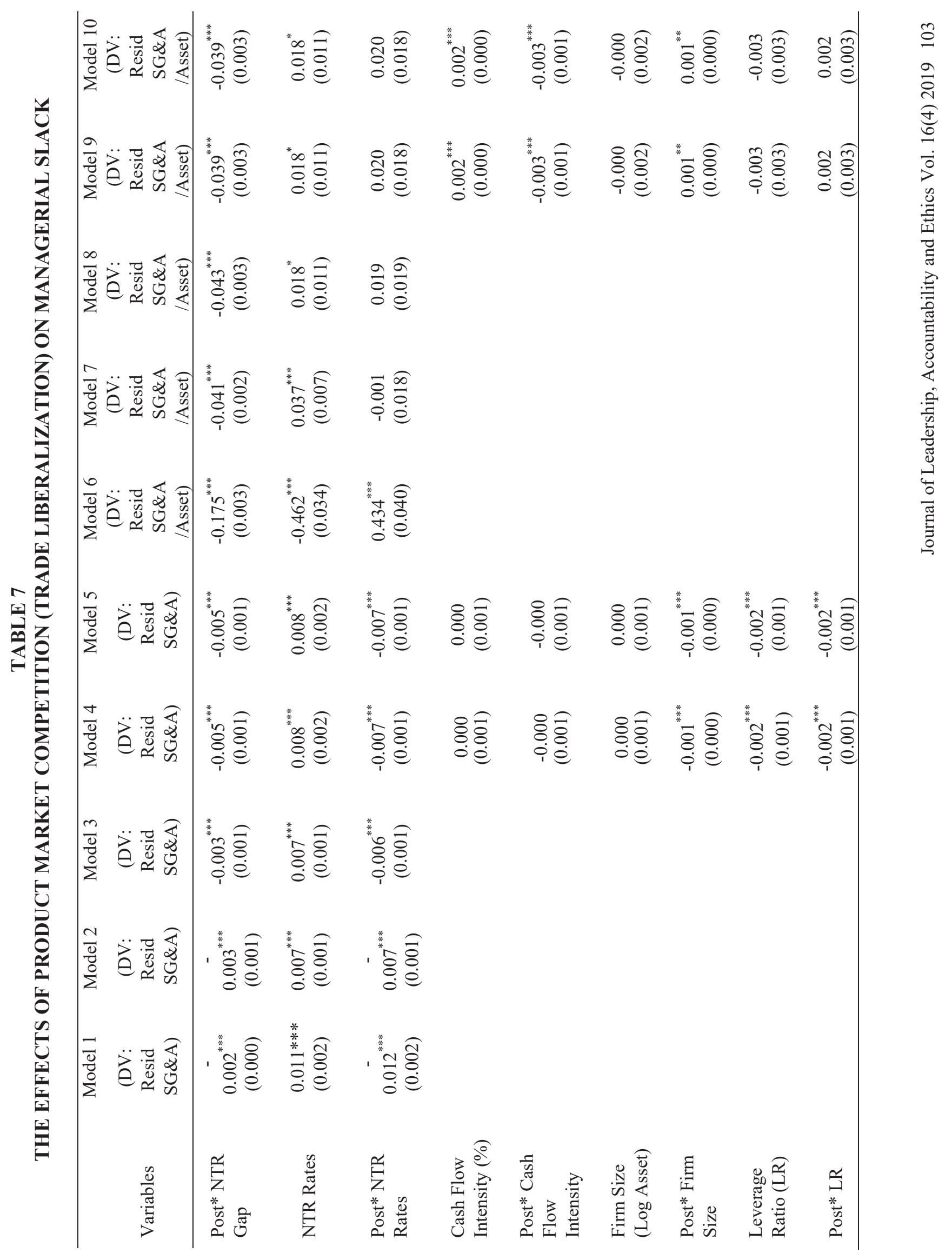




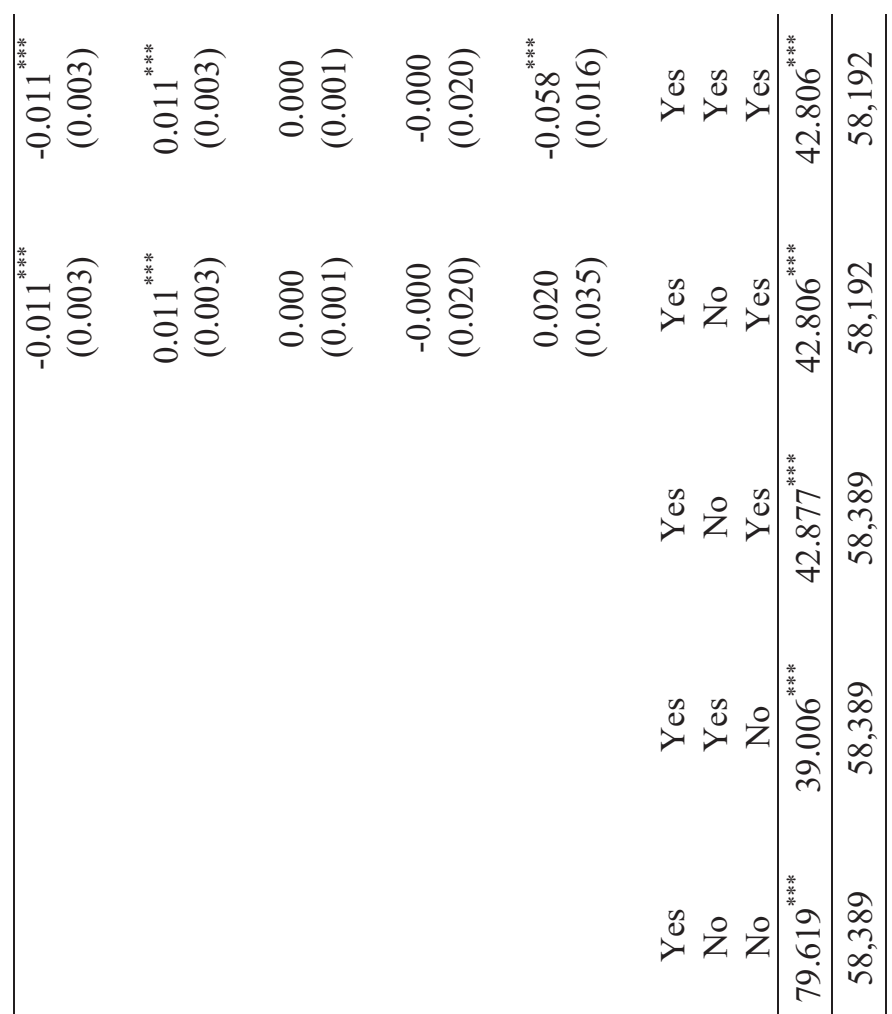

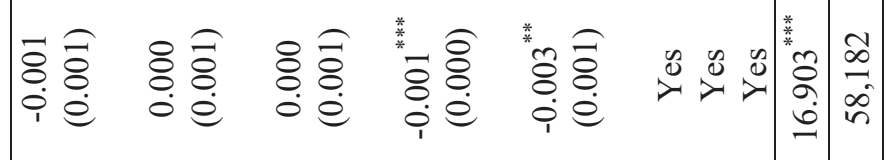

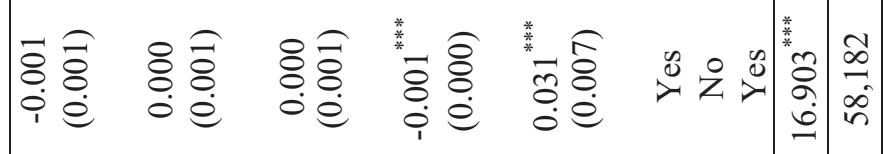

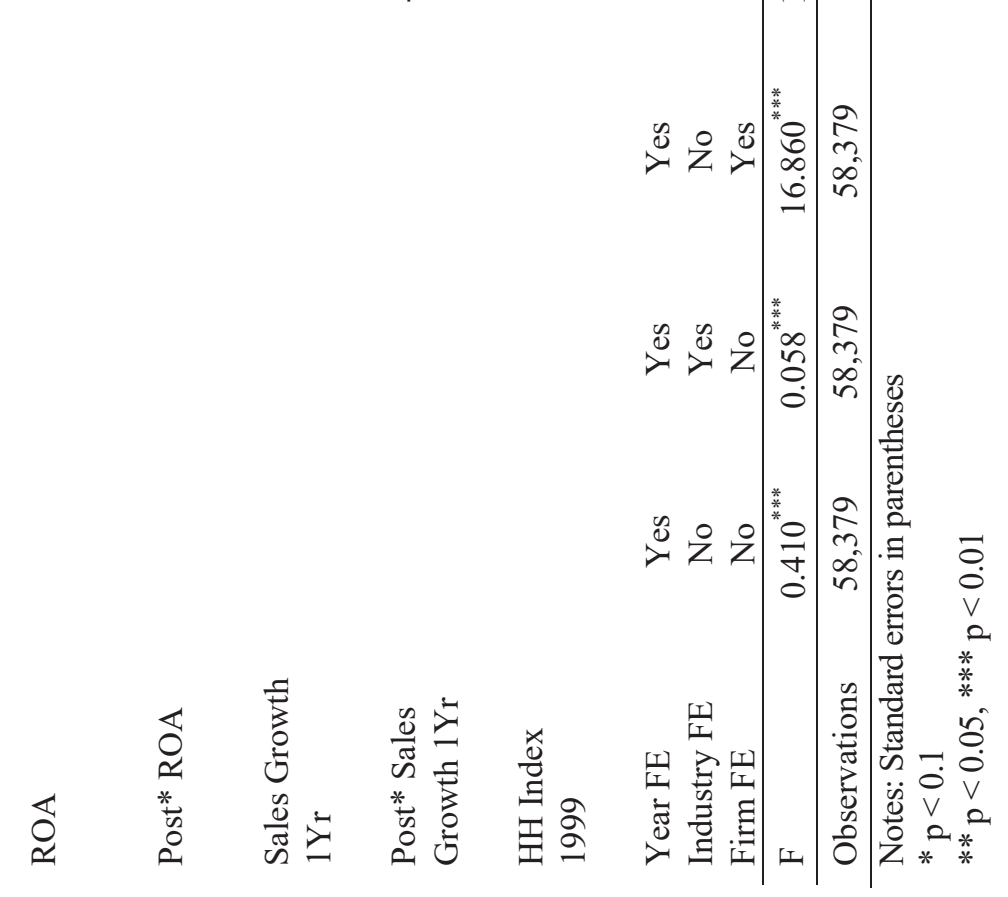


Note that the coefficients on above regressions are the average treatment effect among all industries with positive NTR-Gap after the policy change. However, this effect could not possibly be uniform across all industries. Some US industries, benefiting from lower initial competition, were monopolized. Some industries were already setting prices at the marginal cost due to higher initial competition. So, the latter type might not be affected much even by tariff reduction while the former will lose more market share and experience lower market power. Therefore, the trade policy change could have a differential effect on the treatment group. We take two approaches in order to address this issue and increase the accuracy of the results. First, we added HH-Index in the year 1999 to control for the initial market competition. As shown in tables 4 through 7, adding this industry covariate does not change the significance of our estimates. Second, in the robustness checks, we divide the sample into three groups of low, medium, and high HH-Index. In all groups, the coefficients are still significant at 1\% level.

\section{Robustness Checks}

We check the robustness of the estimates in several ways. First, as mentioned above, we divide the sample into three terciles based on the initial competition measured by HH-Index at 1999. More oligopolistic industries were affected less by the trade shock compared to industries where competition was initially higher. A $1 \%$ higher initial gap leads to $3.9 \%$ and $1.7 \%$ reduction in managerial slack for first and third terciles, respectively. However, the coefficients are robust and significant in all specifications. Next, we check whether the average treatment effect is different for firms of different size. We split the sample into three groups based on the total annual sale and total employment as two measures of firm size. The effect of trade shock was higher for smaller firms, showing that smaller firms respond more significantly to an external shock compared to larger firms. This is in line with the results of splitting the sample based on HH-Index; firms operating in lower market concentration reduced their managerial slack more than firms in more concentrated industries. But the results are all significance and substantive. A $1 \%$ increase in the gap is associated with $5.6 \%, 3.15 \%$, and $0.95 \%$ reduction in managerial slack among firms in the first, second, and third terciles of employment. Similar results are obtained by dividing the sample based on the total annual sale. A $1 \%$ higher initial gap lowers the managerial slack by $3.7 \%, 2.9 \%$, and $1.3 \%$ for firms in the first, second, and third terciles of the total sale. Due to space limitations, the results are not reported here. The authors are committed to provide the tables and replication codes in case of any inquiry.

The base time window in this research was 10-years covering 1990-2010. This feature captures the dynamics and characteristics of firms well before and after the trade policy change. A trade policy change encourages Chinese firms to target the US market. The industries that benefited from the US policy experienced higher growth in profit and so more new firms entered into these markets. The effects of these new entrants in the US local market cannot be revealed in the short run. Therefore, a longer time window was selected in this study to assess the effects of both incumbents and entrants. However, to check the robustness of this time window selection, we use three other time spans covering the years 1992-2009, 1995-2005, and 1998-2002. A 1\% higher gap is reflected in $1.7 \%, 1.2 \%$, and $0.67 \%$ decrease in managerial slack for the three time windows mentioned above, respectively, and all significant at $1 \%$ level.

\section{DISCUSSION}

Devising effective governance mechanisms for aligning managers and shareholders' interests and limiting managerial opportunism is one of the main concerns of corporate governance literature (Hoskisson, Wan, Yiu, \& Hitt, 1999). Despite voluminous research in this area, findings relating governance mechanisms to firm performance, and thus indicative of their effectiveness, have been inconsistent (Dalton et al., 1998; Dalton \& Dalton, 2011). Recently, scholars have proposed that this lack of consistent findings can be a result of considering different governance mechanisms as acting independent of each other and using a single mechanism to predict firm performance (Aguilera et al., 2008; Dalton et al., 2003; Walls, Berrone, \& Phan, 2012). Accordingly, an increasing number of studies 
have been dedicated to studying bundles of governance mechanisms and revealing interdependencies among various types of mechanisms, some arguing for their substitutability and some for their complementarity. In this paper, we provide a quasi-natural experiment as an empirical test of the substitution perspective, which inherently involves a causal relationship between different types of governance mechanisms (Aguilera et al., 2015). We argue that when an exogenous shock increases the strength of an external governance mechanism, there will be less need for an internal one; thus, firms will decrease the strength of their internal governance mechanism in an effort to maintain efficiency and the cost-benefit balance of governance. Using large tariff reductions of the year 2000 as an exogenous shock in product market competition, we investigated whether this shock leads to a decrease in strength of internal governance mechanism of shareholder rights, thus substituting for it. We found support for such an effect. Furthermore, our findings that an exogenous increase in product market competition leads to a decrease in managerial slack, sheds light on the mechanism through which product market competition mitigates the agency problem.

\section{Theoretical Contributions and Practical Implications}

Our paper makes several contributions to strategic management research. First, we contribute to the extant literature on bundles of governance mechanisms. As it was discussed before, research in this area has implications for the broader corporate governance literature. In the light of theoretical arguments and empirical findings on bundles of governance mechanisms, the relationships previously found between a single mechanism and firm outcomes need to be reconsidered. For instance, a lack of significant relationship between board independence and firm performance may be explained by the existence of other governance mechanisms which at low levels of board independence substitute for it but haven't been included in the models.

Second, we answer governance researchers' calls to treat firms' governance mechanisms as endogenous and utilize methodologies that enable tests of causal relationships among these mechanisms (Aguilera et al., 2015). Any attempt to establish the merits of the substitution perspective needs to empirically validate its main argument that an increase in one governance mechanism is accompanied by a decrease in another one (Rediker \& Seth, 1995). Our quasi-natural experiment helps establish causality and rule out alternative explanations for the negative relationship between product market competition and the level of shareholder rights in firms' governance provisions, i.e., the quasi-experimental design enhances the internal validity of our research. Such a causal inference acts as a validation of the substitution perspective.

Third, we extend prior work in corporate governance in general and in substitution perspective in particular by "bringing external corporate governance into the corporate governance puzzle" (Aguilera et al., 2015: 483). Most previous work on bundles of governance mechanisms has focused on the relationship between various internal governance mechanisms, assuming that external governance mechanisms are activated when internal mechanisms have failed (Daily, Dalton, \& Cannella, 2003; Johnson, Hoskisson, \& Hitt, 1993; Walsh \& Seward, 1990). By showing how an exogenous change in external mechanisms can affect internal ones, we demonstrate that external mechanisms can in fact affect internal mechanisms. Moreover, our results of Hypothesis 2 show that external mechanisms can impact the overall effectiveness of firm governance in ensuring that managers reduce their self-interested actions and act in the interest of shareholders.

Fourth, we contribute to the managerial slack literature by directly testing the causal effects of product market competition on managerial slack. Our design allows us to overcome the endogeneity issues with respect to managerial activities in competitive markets. Furthermore, we utilize a recently introduced residual analysis to measure managerial slack. Developed by Fang and colleagues (2018), this measure assesses slack as excess general and administrative expenses, i.e., as a deviation from the predicted level of expense based on several characteristics of the firm. Such a technique for measuring slack helps to isolate excess expenses which are outcomes of managerial decisions to increase their personal benefits. 


\section{Practical Implications}

Our results have practical implications for policy makers. Our findings that managerial slack is in fact lower in competitive industries imply that policy efforts to mitigate shareholder-manager agency problems might benefit from focusing mainly on less competitive or noncompetitive industries. Furthermore, such efforts could also be extended to include attempts aimed at enhancing an industry's competitiveness, for instance through deregulation.

\section{Limitations and Future Research Directions}

We recognize that as with all research our study has several limitations. Future research should examine these limitations and consider other insightful directions to further the study's utility. First, although we demonstrated that product market competition disciplines managers and reduces their excess personal expenses, we didn't show that this reduction is associated with an enhanced financial performance of firms. Future studies examining the relationships between managerial slack and firm performance would provide a better understanding of the effects of product market competition.

Second, we focused on the effects of product market competition on one type of internal governance mechanisms, namely the firm's provisions of shareholder rights. For instance, we didn't examine the effects of an exogenous increase in competition on incentive alignment mechanisms of executives' contingent compensation and equity ownership. Nevertheless, our results show that more research on the area of bundles of governance mechanisms is fruitful and merits attention. Future research that examines interdependent relationships between other governance mechanisms is warranted.

Third, we didn't consider the contingency effects of the national context in which firms operate. In this study we focused on the effects of product market competition on US firm; therefore, the external validity of our results may be limited to this context. It may be that the efficient bundle of governance mechanisms and shareholder and managers responses to changes in the product market competition are different across different countries. Thus, another future direction will be to examine the relationships of governance mechanisms in other countries.

Fourth, an increase in import and market competition could phase out firms that have higher levels of managerial slack. The bankruptcy of these firms leaves the sample of analysis with firms that had initially optimized their performance. This fact leads to a selection issue: the observed firms are the survivors that were experiencing high firm performance. Therefore, the estimated results give us a floor of the real effect of competition on firm performance and should be interpreted with caution. Future research could address this selection issue by using the bankrupted firms' data. The same DID strategy has the potential to investigate whether this increase in the competition had an effect on firms' bankruptcy.

\section{CONCLUSION}

Lack of consistent findings on the link between various governance mechanisms and firm performance can be attributed to a failure to take a holistic picture of how the interdependencies of governance mechanisms influence the effectiveness of each of them. Such a holistic picture can show how governance mechanisms form a bundle and interrelate by either substituting or complementing each other. In this paper, we sought to test the substitution perspective by investigating how the level of shareholder rights, as an important type of internal governance mechanism, is dependent on the extent of competition in the product market, which is an important external mechanism. Furthermore, we examined the effects of product market competition on managerial slack. Utilizing trade liberalization of the year 2000 as a quasi-natural experiment to obtain an exogenous change in product market competition, we found that an increase in product market competition leads to a decrease in the level of shareholder rights and managerial slack. Our study sheds light on the prevalent opportunities in the area of bundles of governance mechanisms. 


\section{ENDNOTE}

1. Manufacturing sector is disaggregated into 5 segments including: food, tobacco, apparel, and textile mill products (labeled 1); lumber, wood, furniture, fixture, paper, printing, and publishing products (labeled 2); chemicals, petroleum refining, rubber, and leather products (labeled 3); stone, clay, primary and fabricated metal, glass, computer equipment, and machinery products (labeled 4); electrical equipment, transportation equipment, measuring and controlling equipment, and miscellaneous manufacturing products (labeled 5).

\section{REFERENCES}

Agrawal, A., \& Knoeber, C. R. (1996). Firm performance and mechanisms to control agency problems between managers and shareholders. Journal of Financial and Quantitative Analysis, 31, 377397. doi: $10.2307 / 2331397$

Aguilera, R. V., Desender, K., Bednar, M. K., \& Lee, J. H. (2015). Connecting the dots: Bringing external corporate governance into the corporate governance puzzle. The Academy of Management Annals, 9, 483-573. doi: 10.5465/19416520.2015.1024503

Aguilera, R. V., Filatotchev, I., Gospel, H., \& Jackson, G. (2008). An organizational approach to comparative corporate governance: Costs, contingencies, and complementarities. Organization Science, 19, 475-492. doi: 10.1287/orsc.1070.0322

Autor, D., Dorn, D., \& Hanson, G. (2018). When work disappears: Manufacturing decline and the falling marriage-market value of young men. American Economic Review: Insights. Doi: $10.3386 / \mathrm{w} 23173$

Beiner, S., Schmid, M. M., \& Wanzenried, G. (2011). Product market competition, managerial incentives and firm valuation. European Financial Management, 17, 331-366. doi: 10.1111/j.1468036x.2009.00505.x

Bell, A., \& Jones, K. (2015). Explaining fixed effects: Random effects modeling of time-series crosssectional and panel data. Political Science Research and Methods, 3, 133-153. doi: $10.1017 /$ psrm. 2014.7

Bell, R. G., Filatotchev, I., \& Aguilera, R. V. (2014). Corporate governance and investors' perceptions of foreign IPO value: An institutional perspective. Academy of Management Journal, 57, 301-320. doi: 10.5465/amj.2011.0146

Betty, B., \& Zajac, E. (1994). Managerial incentives, monitoring and risk of executive compensation, ownership and board structure in initial public offering. Administrative Science Quarterly, 39, 313-335. doi: $10.2307 / 2393238$

Boyd, B. K. (1994). Board control and CEO compensation. Strategic Management Journal, 15, 335-344. doi: $10.1002 / \mathrm{smj} .4250150502$

Chen, C. X., Lu, H., \& Sougiannis, T. (2012). The agency problem, corporate governance, and the asymmetrical behavior of selling, general, and administrative costs. Contemporary Accounting Research, 29, 252-282. doi: 10.1111/j.1911-3846.2011.01094.x

Daily, C. M., Dalton, D. R., \& Cannella Jr, A. A. (2003). Corporate governance: Decades of dialogue and data. Academy of Management Review, 28, 371-382. doi: 10.5465/amr.2003.10196703

Dalton, D. R., Daily, C. M., Certo, S. T., \& Roengpitya, R. (2003). Meta-analyses of financial performance and equity: fusion or confusion? Academy of Management Journal, 46, 13-26. doi: $10.5465 / 30040673$

Dalton, D. R., Daily, C. M., Ellstrand, A. E., \& Johnson, J. L. (1998). Meta-analytic reviews of board composition, leadership structure, and financial performance. Strategic Management Journal, 19, 269-290. doi: 10.1002/(sici)1097-0266(199803)19:3<269::aid-smj950>3.3.co;2-b

Dalton, D. R., \& Dalton, C. M. (2011). Integration of micro and macro studies in governance research: CEO duality, board composition, and financial performance. Journal of Management, 37, 404411. doi: $10.1177 / 0149206310373399$ 
Dalton, D. R., Hitt, M. A., Certo, S. T., \& Dalton, C. M. (2007). 1 The fundamental agency problem and its mitigation: independence, equity, and the market for corporate control. The Academy of Management Annals, 1, 1-64. doi: 10.1080/078559806

Demsetz, H., \& Lehn, K. (1985). The structure of corporate ownership: Causes and consequences. Journal of Political Economy, 93, 1155-1177. doi: 10.1086/261354

Diamond, D. W. (1984). Financial intermediation and delegated monitoring. The Review of Economic Studies, 51, 393-414. doi: 10.2307/2297430

Fama, E. F. (1980). Agency problems and the theory of the firm. Journal of Political Economy, 88, 288307. doi: $10.1086 / 260866$

Fama, E. F., \& Jensen, M. C. (1983). Separation of ownership and control. The Journal of Law and Economics, 26, 301-325. doi: 10.1086/467037

Fang, J., He, L., \& Conyon, M. J. (2018). The CEO Horizon Problem and Managerial Slack in China. Management and Organization Review, 1-34. doi: 10.1017/mor.2017.57

Feenstra, R. C., Romalis, J., \& Schott, P. K. (2002). US imports, exports, and tariff data, 1989-2001 (No. w9387). National Bureau of Economic Research. doi.org: 10.3386/w9387

Feler, L., \& Senses, M. Z. (2017). Trade shocks and the provision of local public goods. American Economic Journal: Economic Policy, 9, 101-143. doi.org: 10.1257/pol.20150578

Finkelstein, S., Hambrick, D. C., \& Cannella, A. A. (2009). Strategic leadership: Theory and research on executives, top management teams, and boards. New York: Oxford University Press.

Flammer, C. (2015). Does product market competition foster corporate social responsibility? Evidence from trade liberalization. Strategic Management Journal, 36, 1469-1485. doi.org: $10.1002 /$ smj. 2307

Giroud, X., \& Mueller, H. M. (2011). Corporate governance, product market competition, and equity prices. The Journal of Finance, 66, 563-600. doi: 10.1111/j.1540-6261.2010.01642.x

Gompers, P., Ishii, J., \& Metrick, A. (2003). Corporate governance and equity prices. The Quarterly Journal of Economics, 118, 107-156. doi: 10.1162/00335530360535162

Goyal, V. K., \& Park, C. W. (2002). Board leadership structure and CEO turnover. Journal of Corporate Finance, 8, 49-66. doi: 10.1016/s0929-1199(01)00028-1

Hambrick, D. C., \& Jackson, E. M. (2000). Outside directors with a stake: The linchpin in improving governance. California Management Review, 42, 108-127. doi: 10.2307/41166056

Hambrick, D. C., Werder, A. v., \& Zajac, E. J. (2008). New directions in corporate governance research. Organization Science, 19, 381-385. doi: 10.1287/orsc.1080.0361

Hart, O. D. (1983). The market mechanism as an incentive scheme. The Bell Journal of Economics, 366382. doi: $10.2307 / 3003639$

Hoskisson, R. E., Wan, W. P., Yiu, D., \& Hitt, M. A. (1999). Theory and research in strategic management: Swings of a pendulum. Journal of Management, 25, 417-456. doi: $0.1177 / 014920639902500307$

Huang, F. L. (2018a). Multilevel modeling and ordinary least squares regression: How comparable are they? The Journal of Experimental Education, 86(2), 265-281. doi: 10.1080/00220973.2016.1277339

Huang, F. L. (2018b). Multilevel modeling myths. School Psychology Quarterly, 33, 492. doi: $10.1037 / \mathrm{spq} 0000272$

Jensen, M. C. (1986). Agency costs of free cash flow, corporate finance, and takeovers. The American Economic Review, 76, 323-329.

Jensen, M. C. (1993). The modern industrial revolution, exit, and the failure of internal control systems. The Journal of Finance, 48, 831-880. doi: 10.1111/j.1540-6261.1993.tb04022.x

Jensen, M. C., \& Meckling, W. H. (1976). Theory of the firm: Managerial behavior, agency costs and ownership structure. Journal of Financial Economics, 3, 305-360. doi: 10.1016/0304405x(76)90026-x

Jensen, M. C., \& Murphy, K. J. (1990). Performance pay and top-management incentives. Journal of Political Economy, 98, 225-264. doi: 10.1086/261677 
Johnson, R. A., Hoskisson, R. E., \& Hitt, M. A. (1993). Board of director involvement in restructuring: The effects of board versus managerial controls and characteristics. Strategic Management Journal, 14, 33-50. doi: 10.1002/smj.4250140905

Luo, W., Zhang, Y., \& Zhu, N. (2011). Bank ownership and executive perquisites: New evidence from an emerging market. Journal of Corporate Finance, 17, 352-370. doi: 10.1016/j.jcorpfin.2010.09.010

Milgrom, P. R., \& Roberts, J. D. (1992). Economics, organization and management. Englewood Cliffs, NJ: Prentice Hall.

Misangyi, V. F., \& Acharya, A. G. (2014). Substitutes or complements? A configurational examination of corporate governance mechanisms. Academy of Management Journal, 57, 1681-1705. doi: 10.5465/amj.2012.0728

Moyer, R. C., Rao, R., \& Sisneros, P. M. (1992). Substitutes for voting rights: Evidence from dual class recapitalizations. Financial Management, 35-47. doi: 10.2307/3666017

Pierce, J. R., \& Schott, P. K. (2016). The surprisingly swift decline of US manufacturing employment. American Economic Review, 106, 1632-1662. doi: 10.1257/aer.20131578

Pierce, J. R., \& Schott, P. K. (2016). Trade liberalization and mortality: Evidence from US counties (No. w22849). National Bureau of Economic Research. doi: 10.3386/w22849

Rediker, K. J., \& Seth, A. (1995). Boards of directors and substitution effects of alternative governance mechanisms. Strategic Management Journal, 16, 85-99. doi: 10.1002/smj.4250160202

Schmidt, K. M. (1997). Managerial incentives and product market competition. The Review of Economic Studies, 64, 191-213. doi: 10.2307/2971709

Schott, P. (2010). US manufacturing exports and imports by SIC or NAICS category and partner country, 1972 to 2005 . Notes.

Schurer, S., \& Yong, J. (2012). Personality, well-being and the marginal utility of income: What can we learn from random coefficient models?

Singh, J. V. (1986). Performance, slack, and risk taking in organizational decision making. Academy of Management Journal, 29, 562-585. doi: 10.5465/256224

Tosi, H. L. Jr., \& Gomez-Mejia, L. R. (1989). The decoupling of CEO pay and performance: An agency theory perspective. Administrative Science Quarterly, 169-189. doi: 10.2307/2989894

Walls, J. L., Berrone, P., \& Phan, P. H. (2012). Corporate governance and environmental performance: Is there really a link? Strategic Management Journal, 33, 885-913. doi: 10.1002/smj.1952

Walsh, J. P., \& Seward, J. K. (1990). On the efficiency of internal and external corporate control mechanisms. Academy of Management Review, 15, 421-458. doi: 10.5465/amr.1990.4308826

Ward, A. J., Brown, J. A., \& Rodriguez, D. (2009). Governance bundles, firm performance, and the substitutability and complementarity of governance mechanisms. Corporate Governance: An International Review, 17, 646-660. doi: 10.1111/j.1467-8683.2009.00766.x

Williamson, O. E. (1964). The economics of discretionary behavior: Managerial objectives in a theory of the firm. Englewood Cliffs, NJ: Prentice Hall.

Wooldridge, J. M. (2015). Introductory econometrics: A modern approach. Great lakes, Canada: Nelson Education.

Yermack, D. (1996). Higher market valuation of companies with a small board of directors. Journal of Financial Economics, 40, 185-211. doi: 10.1016/0304-405x(95)00844-5

Zajac, E. J., \& Westphal, J. D. (1994). The costs and benefits of managerial incentives and monitoring in large US corporations: When is more not better? Strategic Management Journal, 15, 121-142. doi: $10.1002 / \mathrm{smj} .4250150909$

110 Journal of Leadership, Accountability and Ethics Vol. 16(4) 2019 